TITLE:

\title{
MYSIDACEA FROM THE CENTRAL AND WESTERN PACIFIC II. -GENERA HYPERAMBLYOPS, TERATERYTHROPS AND SYNERYTHROPS (TRIBE ERYTHROPINI)-
}

\author{
AUTHOR(S): \\ Murano, Masaaki
}

\section{CITATION:}

Murano, Masaaki. MYSIDACEA FROM THE CENTRAL AND WESTERN PACIFIC II. -GENERA HYPERAMBLYOPS, TERATERYTHROPS AND SYNERYTHROPS (TRIBE ERYTHROPINI)-. PUBLICATIONS OF THE SETO MARINE BIOLOGICAL LABORATORY 1975, 22(1-4): 81-103

\section{ISSUE DATE:}

\section{5-07-31}

URL:

http://hdl.handle.net/2433/175888

RIGHT: 


\title{
MYSIDACEA FROM THE GENTRAL AND WESTERN PAGIFIC II. GENERA HYPER AMBLYOPS, TERATERYTHROPS AND SYNER YTHROPS (TRIBE ERYTHROPINI)
}

\author{
MASAAKI MURANO \\ Tokyo University of Fisheries
}

With Text-figures 1-8

In the present paper the genera Hyperamblyops, Teraterythrops and synerythrops are discussed. Many of the species belonging to these three genera seem to be in confusion with respect to their taxonomy. Fortunately, many specimens of these species were caught in the collections, so I attempted to give the definition of these genera and to clear away the confusion. Moreover, the description on a new species of Synerythrops, S. truncata, and the details of the geographical and vertical distribution of Teraterythrops robusta are also reported.

I should like to express my thanks to Dr. Naoyoshi Ii for his helpful criticism and valuable advice. Thanks are also due to Professor Ryuzo Marumo, Ocean Research Institute, University of Tokyo, for the opportunity of examining the specimens stored in his Institute.

Genus Hyperamblyops Birstein and Tchindonova 1958

Characteristics of the Genus

1. Body short and thick.

2. Eye large, convex-lens-shaped in dorsal view; facets imperfectly developed.

3. Antennal scale short, not extending beyond distal margin of antennular peduncle; spinous process which terminates naked outer margin present or absent.

4. Sympod of antenna unarmed with spinous process at outer distal corner.

5. Telson long linguiform, armed on distal $1 / 2$ to $1 / 3$ with many spines which become progressively longer distally; apical plumose setae present.

Remarks

This genus was instituted by Birstein and Tchindonova in 1958 for the reception of Hyperamblyops nana, and they considered that Dactylamblyops antartica from the Antarctic $\left(53^{\circ} 10^{\prime} \mathrm{S}, 36^{\circ} 21^{\prime} \mathrm{W}\right)$ and Gibberythrops megalops from the west of Cape Town must be included in the present genus. I think that Dactylamblyops japonica Ii from Suruga Bay, Japan, is also certainly contained in the present genus. D. japonica does not agree with the diagnosis defined by Birstein and Tchindonova in the presence

Publ. Seto Mar. Biol. Lab., XXII (1/4), 81-103, 1975.

(Article 5) 
of a prominent terminal spinous process on the outer margin of scale, but it very well agrees with the diagnosis in other characteristics. For the reception of this species it needs to revise a part of the diagnosis of the genus.

The present genus is most related to genus Dactylamblyops, as it was identified by Hansen (1913) and Ii (1964) with that genus at the institution of their species, but is distinguishable from the latter in the short and thick body, the large and lens-shaped eye, the small antennal scale, and the telson with apical plumose setae. From Gibberythrops into which $H$. megalops was originally enrolled by O. Tattersall, the present genus differs in the general form, the imperfectly developed eye and the long linguiform telson.

At present, genus Hyperamblyops is consisting of four species as follows; H. nana Birstein and Tchindonova, $H$. antarctica (Hansen), H. megalops (O. Tattersall) and $H$. japonica (Ii). In the present collections two species, H. nana and H. japonica, were caught.

Key for the identification of the species in the genus Hyperamblyops

1. Anterior margin of carapace produced into a broad, bluntly rounded rostral plate. Telson with 3 apical plumose setae. H. megalops (O. Tattersall)

(West of Cape Town)

- Anterior margin of carapace produced into more or less triangular rostral plate with rounded tip. Telson with a pair of apical plumose setae.

H. antarctica (Hansen)

(Antarctic)

2. First thoracic limb without lobe on second segment of endopod.

- First thoracic limb with lobe on second segment of endopod. 3

3. Antennal scale without a terminal spinous process on outer margin. H. nana Birstein and Tchindonova (Kurile Is., Japan)

- Antennal scale with a terminal spinous process on outer margin. H. japonica (Ii) (Japan)

\section{Hyperamblyops nana Birstein and Tchindonova 1958}

Hyperamblyops nana Birstein and Tchindonova, 1958: 314-316.

Occurrence:

St. 77,1 adult male $(8.9 \mathrm{~mm})$.

St. 80,1 near adult male $(6.9 \mathrm{~mm})$.

St. 107,1 adult male $(7.5 \mathrm{~mm})$.

St. 185, 1 adult female $(8.0 \mathrm{~mm})$ and 2 immature males $(7.0$ and $7.0 \mathrm{~mm})$.

St. 196-2, 1 adult $(8.2 \mathrm{~mm})$ and 1 immature $(6.2 \mathrm{~mm})$ females.

St. 258-11, 1 immature female $(6.0 \mathrm{~mm})$ and 1 young form $(3.4 \mathrm{~mm})$.

St. H9 $-8,1$ immature female $(4.4 \mathrm{~mm})$.

Remarks:

The present specimens agree very well with the description and figures on the type specimens, but the difference is found in the body length. In the type specimens it was recorded to be up to $13 \mathrm{~mm}$, whereas in the present specimens the maximum 
body length was $8.9 \mathrm{~mm}$ in male and $8.2 \mathrm{~mm}$ in female.

Hyperamblyops nana is closely allied to $H$. antarctica recorded from the Antarctic Ocean. The most remarkable difference in the both species is found in the presence or absence of the lobe on the second segment of endopod of first thoracic leg. There is a doubt that the lack of this lobe in the latter species may be due to overlooking, so that a full examination of the next specimen from the Antarctic is needed.

Geographical distribution:

The types were taken from the Kurile-Kamtchatka Trench and there have been no other records until the present ones from off Central Japan.

Vertical distribution:

The present species is a bathypelagic form which was never collected when the net did not attain to the layers deeper than $1000 \mathrm{~m}$. In the horizontal tow of the ORI-net with opening-closing system the species was obtained at the layers of 1550 $1750 \mathrm{~m}$ and $1300-1700 \mathrm{~m}$. It is hard to suppose that the species ascend to euphotic zone at night (Table 1).

Table 1. Collection records of Hyperamblyops nana in relation to the vertical distribution.

\begin{tabular}{ccc}
\hline Station & Depth $(\mathrm{m})$ & $\begin{array}{c}\text { Number of } \\
\text { individuals collected }\end{array}$ \\
\hline 77 & $0-1800^{*}$ & 1 \\
80 & $0-1260^{*}$ & 1 \\
107 & $0-2000^{* *}$ & 1 \\
185 & $0-2000^{*}$ & 3 \\
$196-2$ & $0-2100^{*}$ & 2 \\
$258-11$ & $1550-1750^{*}$ & 1 \\
H9-8 & $1300-1700^{*}$ & 1 \\
\hline
\end{tabular}

* The depth is estimated from the TSK Depth-Distance Recorder.

** The depth is calculated from the wire angle and wire length.

\section{Hyperamblyops japonica (Ii) 1964}

Dactylamblyops japonica Ii, 1964: 293-296.

Occurrence:

St. 76-2, 27 adult and immature females $(5.5-9.0 \mathrm{~mm}), 21$ adult and immature males $(6.7-9.5 \mathrm{~mm})$ and 6 young forms $(4.3-5.6 \mathrm{~mm})$.

St. 77,1 immature female $(7.6 \mathrm{~mm})$.

St. 107,1 adult female $(6.7 \mathrm{~mm})$.

St. 111-2, 2 immature females $(6.2$ and $7.0 \mathrm{~mm})$.

Remarks:

The present species was firstly reported by Ii for an immature couple from Suruga Bay in 1964 under the specific name of Dactylamblyops japonica. As stated in the paragraph of the genus, it is impossible to refer them to Dactylamblyops. In the present collections an adult female $9.0 \mathrm{~mm}$ long and an adult male $9.5 \mathrm{~mm}$ long 
were collected. They agree very well with Ii's description and figures on the type specimens, but there are some differences which are maybe resulted from the stages of growth in the following respects: the relative length between the antennal peduncle and the scale, the number of spines on the lateral margin of telson, and the developmental difference in male pleopods.

The present species resembles $H$. nana so closely that it may be better to unite these two species. However, the presence of the spinous process terminating the outer margin of scale in the present species is the most remarkable difference between them. This fact seems to be a sufficient evidence by which the present species is separated from $H$. nana. In addition to the antennal scale, the minute differences are found in the size of eye and the shape of frontal margin of carapace. At. Sts. 77 and 107 the both species were caught together in one hauling of a net, so that it is hard to consider that the differences are originated in the geographical variation.

Geographical distribution:

The present species is only known from Suruga Bay, Japan, and its just adjacent waters.

Vertical distribution:

The type specimens of this species were caught by a vertical haul from the $1410 \mathrm{~m}$ depth to the surface in Suruga Bay. In the present collections all the specimens were obtained by oblique hauls which the net attained to the layers deeper than $1430 \mathrm{~m}$, so that it seems to be a bathypelagic form living in layers deeper than $1000 \mathrm{~m}$ (Table 2).

Table 2. Collection records of Hyperamblyops japonica in relation to the vertical distribution.

\begin{tabular}{clc}
\hline Station & Depth $(\mathrm{m})$ & $\begin{array}{c}\text { Number of } \\
\text { individuals collected }\end{array}$ \\
\hline $76-2$ & $0-2300^{*}$ & 54 \\
77 & $0-1800^{*}$ & 1 \\
107 & $0-2000^{* *}$ & 1 \\
$111-2$ & $0-1430^{*}$ & 2 \\
\hline
\end{tabular}

* The depth is estimated from the TSK Depth-Distance Recorder.

** The depth is calculated from the wire angle and wire length.

\section{Genus Teraterythrops Ii 1964}

\section{Characteristics of the Genus}

1. Eye small and somewhat imperfectly developed.

2. Eyestalk with a small digitiform process on upper surface near distal inner corner of stalk.

3. Antennal scale small, not extending to distal margin of antennular peduncle.

4. Telson short triangular with truncate apex, armed on apex with a pair of slender spines and a pair of plumose setae and on distal part of lateral margin with a few spines which become progressively longer distally. 


\section{Remarks}

In 1914 Zimmer instituted a new species Katerythrops parva for the reception of a specimen collected from equatorial region of the Atlantic Ocean.

In 1958 Birstein and Tchindonova instituted a new species Synerythrops robusta, and they replaced Zimmer's species $K$. parva to genus Synerythrops from the resemblance between both species.

In 1964 Ii created a new genus and a new species, Teraterythrops tanakai, based on specimens captured from Sagami and Suruga Bays.

Through the examination of a number of the present specimens, I have no doubt at all that two species of these three species, $S$. robusta and $T$. tanakai, are synonymous. The priority must be given to $S$. robusta named by Birstein and Tchindonova. However, Ii stated in his paper when he created a new genus and a new species as follows: "In the form and armature of the telson the present species almost absolutely agrees with Synerythrops intermedia, described by Hansen. By reason of the somewhat different characters of the eye, antennal scale, second maxilla and pseudobranchial process on the male pleopod, I cannot refer the present species to Synerythrops." I subscribe to his opinion and should like to accept Teraterythrops as the genus name for the present species, but species name tanakai must be replaced with the earlier name of robusta.

The species, which was originally named by Zimmer Katerythrops parva and later by Birstein and Tchindonova with Synerythrops parva, is also in need of the transfer to the present genus.

Then, the genus is constituted with only two species: T. robusta and T. parva. There is only one species, $T$. robusta, in the present collections.

Key for the identification of the species in the genus Teraterythrops.

1. Terminal spine of naked outer margin of scale not extending beyond apex of scale. Telson armed with a pair of spines on apex and with 1 spine on each lateral margin near apex.

T. parva (Zimmer) (Equatorial Atlantic)

- Terminal spine of naked outer margin of scale extending beyond apex of scale. Telson armed with a pair of spines on apex and with about 3 spines on each lateral margin near apex.

T. robusta (Birstein and Tchindonova)

(Central and western North Pacific)

\section{Teraterythrops robusta (Birstein and Tchindonova) 1958}

Synerythrops robusta Birstein and Tchindonova, 1958: 317-318.

Teraterythrops tanakai Ii, 1964: 298-301.

Occurrence:

St. 6-5, 1 female.

St. $67-5,1$ female.

St. 76-2, 13 females and 8 males.

St. 78, 1 female.

St. 83, 2 females.

St. 93-2, 3 females and 2 males.
St. 53, 1 female.

St. 67-7, 5 females and 4 males.

St. 77, 15 females and 3 males.

St. 80, 4 females and 1 male.

St. 84-3, 1 female.

St. 94, 3 females and 1 male. 
St. 95, 1 female.

St. 104-6, 1 male and 2 young forms.

St. 107, 6 females and 7 males.

St. 110, 4 females and 3 males.

St. 112, 2 females and 2 males.

St. 115-2, 1 male.

St. 120, 1 female.

St. 128-5, 6 females and 1 male.

St. 139, 1 female.

St. 145-4, 1 young form.

St. 152, 3 females.

St. 155,1 female.

St. 157, 6 females.

St. 159, 6 females and 1 male.

St. 161, 1 female and 2 males.
St. 104-2, 2 females.

St. 104-8, 2 females.

St. 108, 7 females and 2 males.

St. 111-2, 4 females and 1 male.

St. 114, 1 female.

St. 118, 4 females and 1 male.

St. 121-2, 3 females and 1 male.

St. 138, 1 female and 1 male.

St. 144-3, 1 female.

St. 146-4, 1 female.

St. 154, 8 females.

St. 156-1, 6 females and 1 male.

St. 158-1, 6 females.

St. 160, 8 females.

St. 169-3, 2 females and 1 young form.

St. 169-4, 8 females, 2 males and 2 young forms.

St. 176-6, 2 females.

St. $177-5,10$ females, 1 male and 1 young form.

St. 177-6, 2 males.

St. 179-4, 1 female.

St. 179-6, 2 females and 2 males.

St. 180-4, 1 female.

St. 182, 6 females.

St. 185, 4 females, 5 males and 1 young form.

St. 190-7, 1 female and 2 males.

St. 192, 1 male.

St. 194-2, 2 females and 1 male.

St. 196-2, 3 females and 1 male.

St. 197-1, 1 male.

St. 197-2, 6 females.

St. 200, 1 female and 2 males.

St. 206, 1 male.

St. 213, 1 female.

St. 224-6, 5 females and 5 males.

St. 224-10, 2 females.

St. 225-9, 4 females and 2 males.

St. 225-10, 1 female.

St. 228, 11 females.

St. 313, 1 female.

St. 344, 5 females and 4 males.

St. 345, 1 female and 1 male.

St. 363-7, 2 females.

St. 457, 4 females.

St. 526, 2 females.

St. 589, 2 females.

St. H9-1, 1 female.

St. H9-4, 1 male.

St. H9-8, 3 females and 2 males.

St. H9-10, 1 female.

St. H10-4, 3 females.

St. H10-11, 9 females and 6 males.

St. H67-1, 1 female.

St. H84-9, 2 females.

St. H90-6, 1 female.

St. H9l-1, 4 males.

St. H93-1, 1 female.

Body length:

Female up to $7.7 \mathrm{~mm}$, male up to $7.5 \mathrm{~mm}$.

Remarks:

As noted in the paragraph of the genus, the present species cannot belong to genus Synerythrops, and it is to be placed in genus Teraterythrops. 
Geographical distribution:

Previously, our knowledge of the geographical distribution of this species was poor since we have had only two records, from the western North Pacific east of Japan by Birstein and Tchindonova (1958) and from Sagami and Suruga Bays by Ii (1964). The present collections gave us fairly well the knowledge of the distribution (Fig. 1).

T. robusta is commonly distributed in the West Pacific off the Pacific coast of Japan from $44^{\circ} \mathrm{N}$ to $28^{\circ} \mathrm{N}$, especially in Sagami Bay and Suruga Bay. Most of the stations where the species was taken were situated in the Western North Pacific

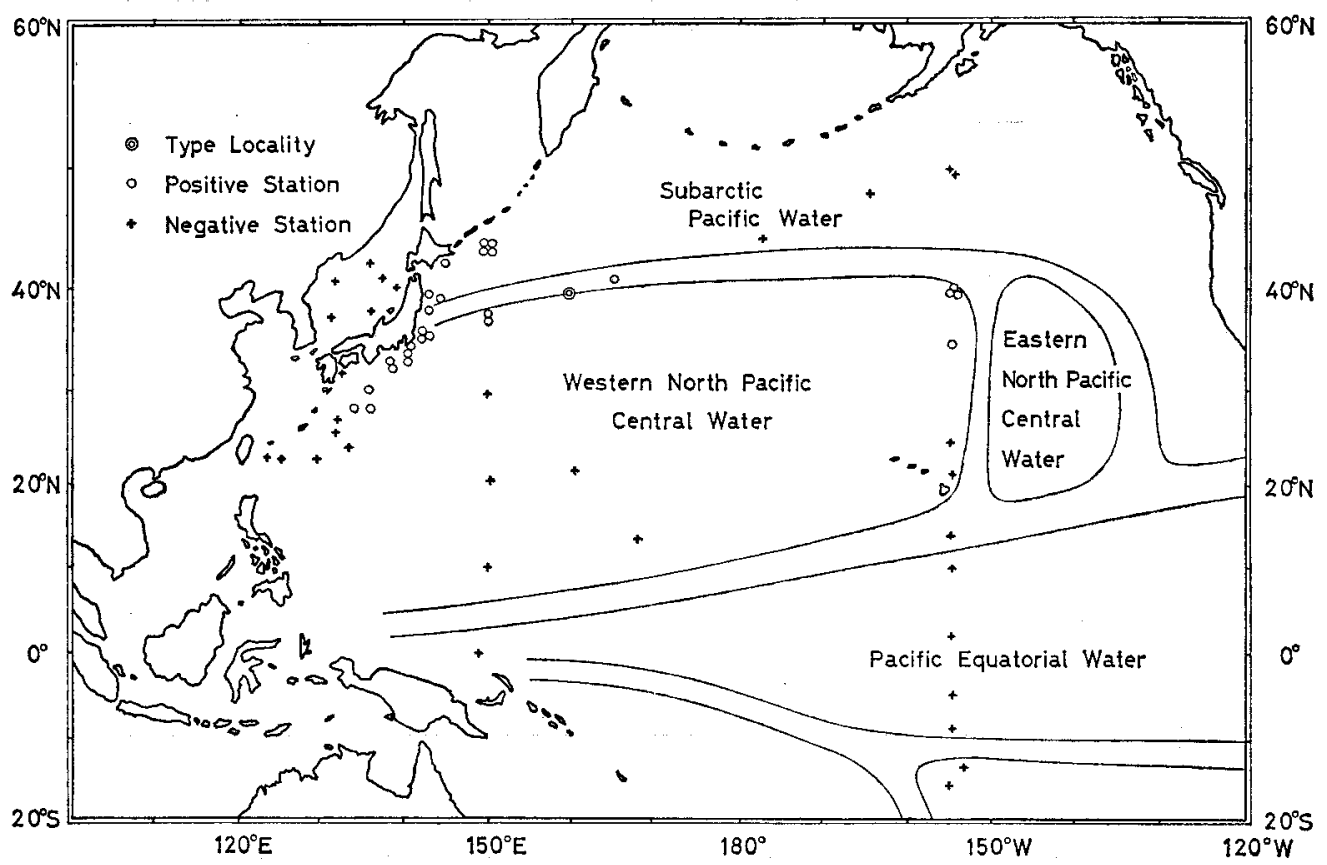

Fig. 1. Geographical distribution of Teraterythrops robusta. As to the boundaries of the water masses, reference was made to Sverdrup, Johnson and Fleming (1942) with modification by the oceanographical data of Preliminary Report of the Hakuho Maru Cruise KH-69-4 (IBP Cruise) (1970).

Central Water, but several stations off the coast of northern Japan were in the Subarctic Pacific Water. It was also captured from 4 stations locating in $40^{\circ} \mathrm{N}, 155^{\circ} \mathrm{W}$ and $35^{\circ} \mathrm{N}, 155^{\circ} \mathrm{W}$ far to the north of Hawaiian Islands, and such collections are, of coarse, the easternmost records.

From the Japan Sea the species has not been recorded, and this fact has probably resulted from the topographical condition that the passages between the Pacific Ocean and the Okhotsk Sea or the East China Sea are shallower than the upper limit of the vertical distribution of this species.

Vertical distribution: 
The study on the vertical distribution of plankton and micronekton were carried out in Sagami Bay, Suruga Bay and their adjacent waters in August 1964, July 1966 and April 1967 using a large-sized conical net, the ORI-net, with the mouth diameter of $160 \mathrm{~cm}$. The net was provided with an opening-closing device and was horizontally towed in various mid-layers. In Fig. 2 there are shown 29 horizontal tows which were made at night within the range of vertical distribution of Teratery-

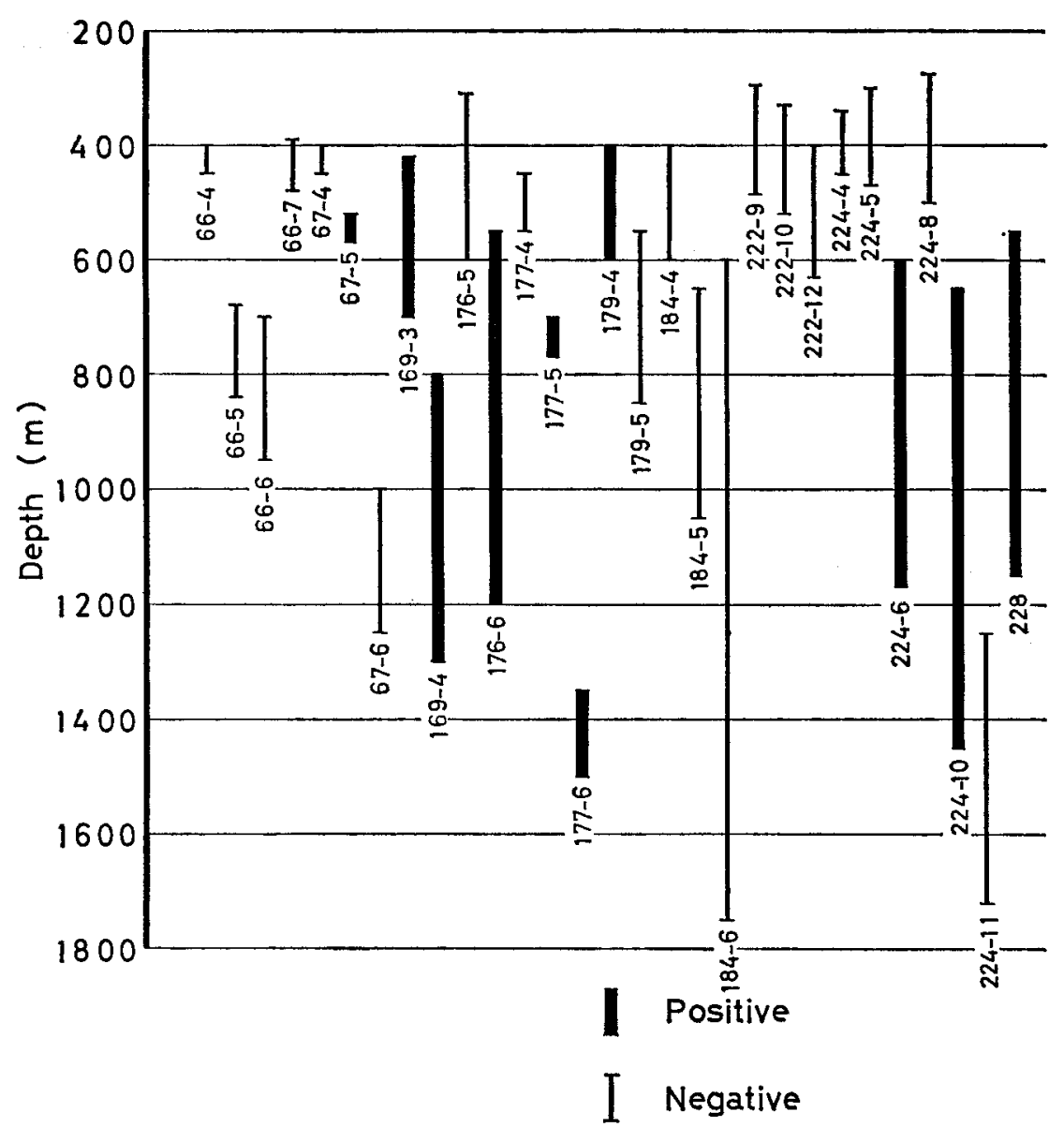

Fig. 2. Depth ranges in 29 horizontal tows with the ORI-net used for the profile of the vertical distribution of Teraterythrops robusta. The numerals show the Station nos.

throps robusta. Out of these, this species was collected in 10 tows between the shallowest depths of 400 to $600 \mathrm{~m}$ and the deepest depths of 1350 to $1500 \mathrm{~m}$. In order to get the profile of vertical distribution, the vertical range between $400 \mathrm{~m}$ and $1500 \mathrm{~m}$ of this species was divided into every $100 \mathrm{~m}$. Then, the individual number per unit water volume was calculated from the number of the specimens and the volume of water filtered. The result was given in Fig. 3. The distribution was found to have two peaks in deeper layers of the depths of 400 to $1500 \mathrm{~m}$, at 700 to $800 \mathrm{~m}$ and at 


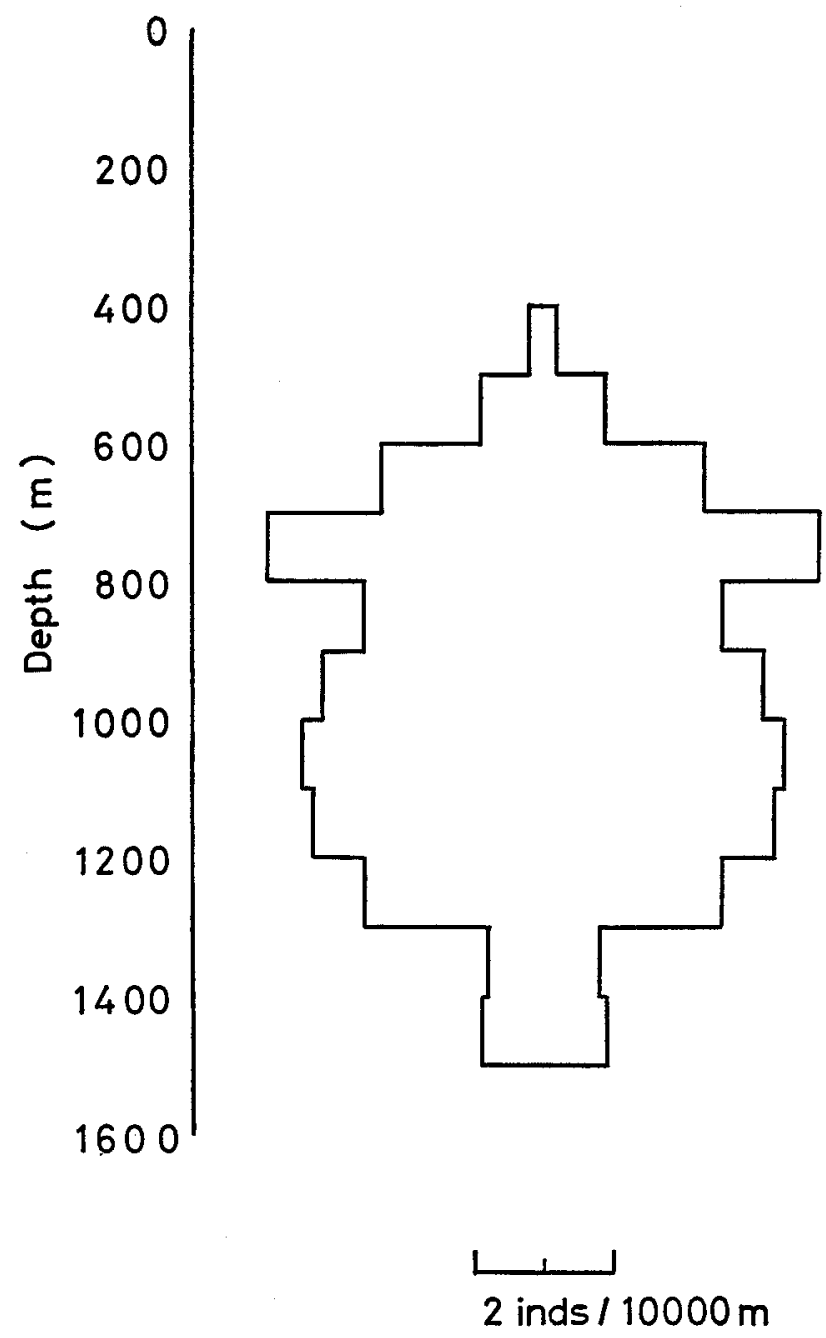

Fig. 3. Vertical distribution of Teraterythrops robusta at night.

Table 3. Collection data of Teraterythrops robusta obtained with the ORI-net with an opening-closing device in the daytime.

\begin{tabular}{clc}
\hline Station & Depth $(\mathrm{m})$ & $\begin{array}{c}\text { Number of } \\
\text { individuals collected }\end{array}$ \\
\hline $104-6$ & $670-800$ & 3 \\
$179-6$ & $700-1000$ & 4 \\
$180-4$ & $500-850$ & 1 \\
$225-9$ & $475-1000$ & 6 \\
$225-10$ & $520-700$ & 2 \\
\hline
\end{tabular}


1000 to $1100 \mathrm{~m}$. Average in the vertical range of distribution was calculated to be $4.4 \mathrm{inds} / 10000 \mathrm{~m}^{3}$, and the maximum value of about 8 inds/ $/ 10000 \mathrm{~m}^{3}$ occurred at the shallower peak of 700 to $800 \mathrm{~m}$. In Table 3 there are given the collection data of five tows when $T$. robusta was collected in the daytime by the ORI-net provided with an opening-closing device. The vertical range of the species was found to be the depths from 475 to $1000 \mathrm{~m}$ and there is no distinct difference from this in the value at night. It is hard to consider that this species performs a diurnal vertical migration.

\section{Genus Synerythrops Hansen 1910}

\section{Characteristics of the Genus}

1. Rostral plate triangular, anteriorly produced between eyes.

2. Eye well developed and globular.

3. Antennal peduncle slender, its second segment connected with ventral side of basal part of third segment.

4. Antennal scale large, much longer than antennular peduncle.

5. Distal segment of endopod of maxilla short, about as long as broad.

6. Telson short, about as long as broad.

\section{Remarks}

The present genus is easily distinguishable in the two characteristics, maxilla with short distal segment of endopod and short telson.

Nowadays, the genus Synerythrops contains the following three species, S. intermedia Hansen, S. cruciata W. Tattersall and $S$. truncata sp. nov., since, as noted above, $S$. robusta and $S$. parva which were, hitherto, members of the genus were transferred to genus Teraterythrops.

W. Tattersall (1939) found so peculiar feature in pleopod of male that the pseudobranchial process on endopods was in the form of a long narrow lobe instead of much shorter platelike appendage. However, I could not mention this as one of the characteristics of the genus because this was not found in the present new species.

Two species of $S$. intermedia and $S$. truncata were obtained in the collections.

Key for the identification of the species in the genus Synerythrops

1. Telson with rather truncate distal margin, armed with 3 pairs of long strong spines on distal margin and with a single small spine at close end of each lateral margin. S. truncata sp. nov. (Japan)

- Telson with rounded distal margin, armed on distal quarter of each margin with about 8 spines which become progressively longer posteriorly.

2. Eye large, extending laterally beyond lateral line of anterior part of body. Rostral plate somewhat short, not extending to distal margin of eye. S. intermedia Hansen (Indonesia, Gulf of Aden and Japan)

- Eye rather small, not extending laterally beyond lateral line of anterior part of body. Rostral plate long, extending forwards beyond distal margin of eye. S. cruciata W. Tattersall (West Indies) 


\section{Synerythrops intermedia Hansen 1910}

(Figs. 4a, 5 and 6)

Synerythrops intermedia Hansen, 1910: 64-65; W. Tattersall, 1939: 237-238.

\section{Occurrence:}

St. $67--1,1$ immature female $(8.4 \mathrm{~mm})$.

St. 202, 1 near adult $(15.4 \mathrm{~mm})$ and 1 immature $(10.9 \mathrm{~mm})$ females.

St. 533, 1 adult female (18.2 $\mathrm{mm})$.

Remarks:

The present species was established in 1910 by Hansen for the reception of a single immature female $7.2 \mathrm{~mm}$ long, collected from Manipa Strait during the cruise of Siboga-Expedition. In 1936, W. Tattersall reported 4 badly damaged specimens

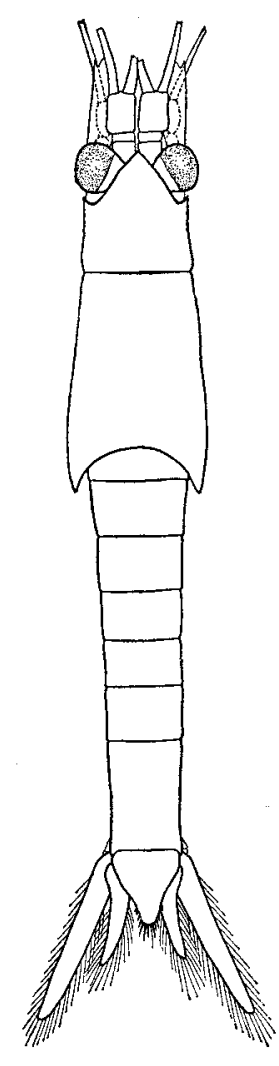

a

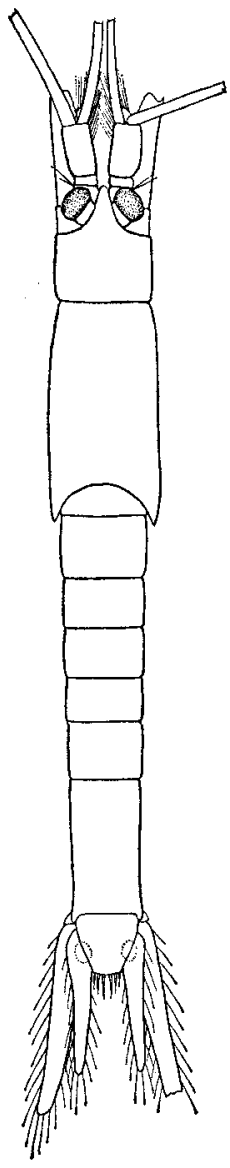

b

Fig. 4. a, Synerythrops intermedia Hansen, near-adult female in dorsal view, $\times 5$;

b, Synerythrops truncata sp. nov, adult male in dorsal view, $\times 8$. 
from Great Barrier Reef and identified them with $S$. intermedia though he had some doubts. However, it does not seem that these specimens belong to this species judging from his description and figure. The third record of the present species was made by W. Tattersall in 1939 for a single male from the Gulf of Aden. In his paper, he

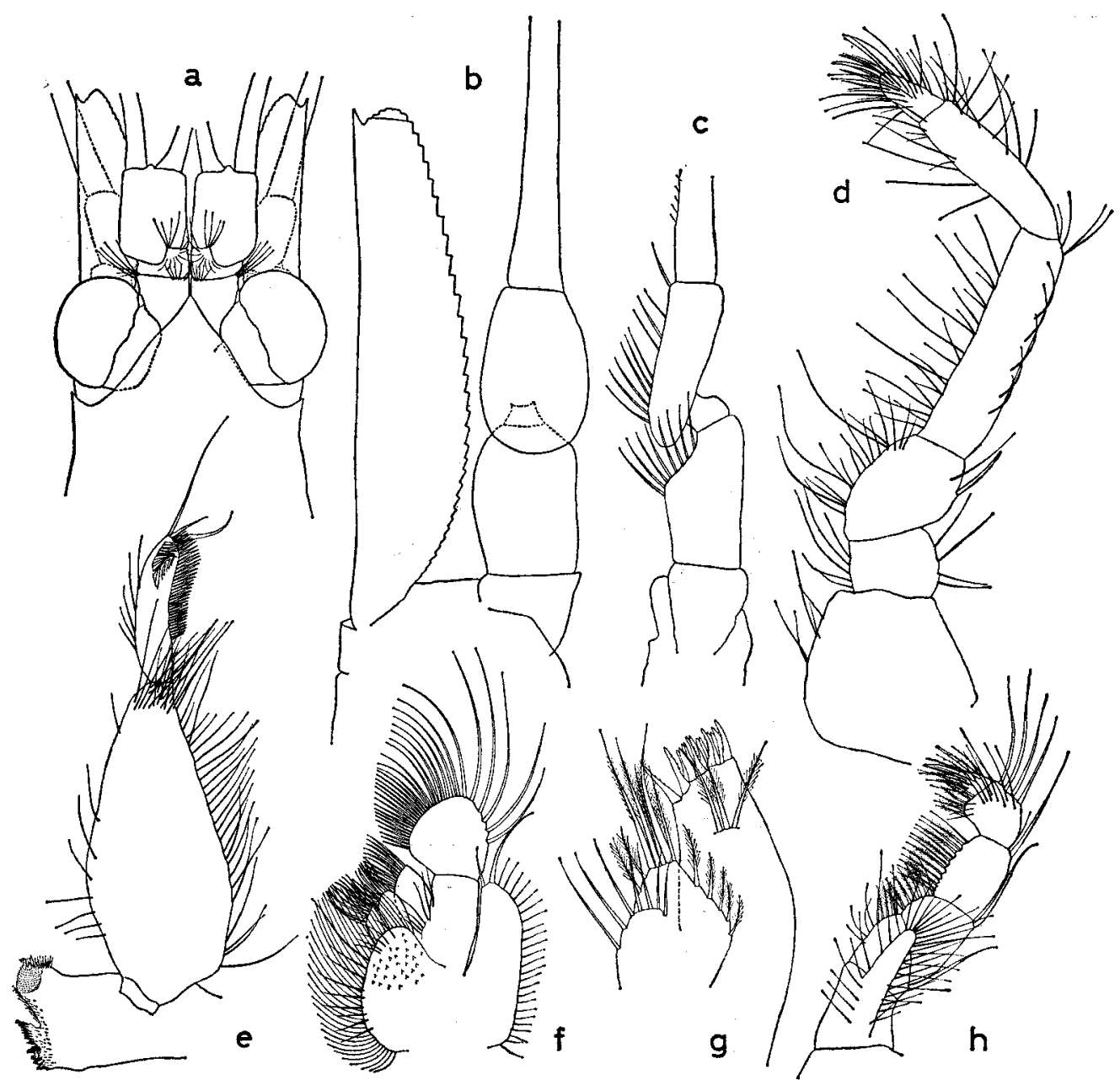

Fig. 5. Synerythrops intermedia Hansen; a, anterior end of near-adult female, $\times 13$; b, antennal peduncle and scale, $\times 25$; , antennal peduncle in lateral view, $\times 25$; d, endopod of second thoracic limb, $\times 25$; e, mandible, $\times 25 ; \mathrm{f}$, maxilla, $\times 25 ; \mathrm{g}$, maxillule, $\times 62 ; \mathrm{h}$, endopod of first thoracic limb, $\times 25$.

reported the presence of a small ocular papilla and an interesting feature of pleopods that the pseudobranchial processes on endopods were in the form of a long narrow lobe. Consequently, only two specimens have previously been known.

Among the present specimens, a near adult female $15.4 \mathrm{~mm}$ long bears a brood pouch though it is not yet fully developed. Between this female and the young type 
specimen $7.2 \mathrm{~mm}$ long several considerable differences are present as shown in Table 4. However, in the shapes of the maxilla and telson the present near adult female agrees very well with the type specimen (Fig. 5, f and Fig. 6, a), and it is thought that the differences in rostrum and scale are caused by the stages of growth, because an immature female of $10.9 \mathrm{~mm}$ in the present collection has a rostrum with a rounded tip and an antennal scale extending beyond the antennular peduncle by only distal

Table 4. Main differences between the type specimen and the present near-adult specimen from Japan.

\begin{tabular}{|c|c|c|}
\hline & $\begin{array}{c}\text { Type specimen } \\
(7.2 \mathrm{~mm})\end{array}$ & $\begin{array}{l}\text { Present near-adult } \\
\text { specimen }(15.4 \mathrm{~mm})\end{array}$ \\
\hline Rostrum & $\begin{array}{l}\text { Moderately broadly } \\
\text { rounded. }\end{array}$ & $\begin{array}{l}\text { Obtusely pointed } \\
\text { (Fig. } 6, \text { a). }\end{array}$ \\
\hline Antennal scale & $\begin{array}{l}\text { Slightly overreaching } \\
\text { antennular peduncle. } \\
\text { Somewhat less than } 4 \\
\text { times as long as broad. }\end{array}$ & $\begin{array}{l}\text { Extending beyond } \\
\text { antennular peduncle by } \\
\text { about } 1 / 3 \text { of length of } \\
\text { scale (Fig. } 6 \text {, a). } \\
\text { About } 4.5 \text { times as } \\
\text { long as broad (Fig. } 6, \mathrm{~b} \text { ). }\end{array}$ \\
\hline
\end{tabular}

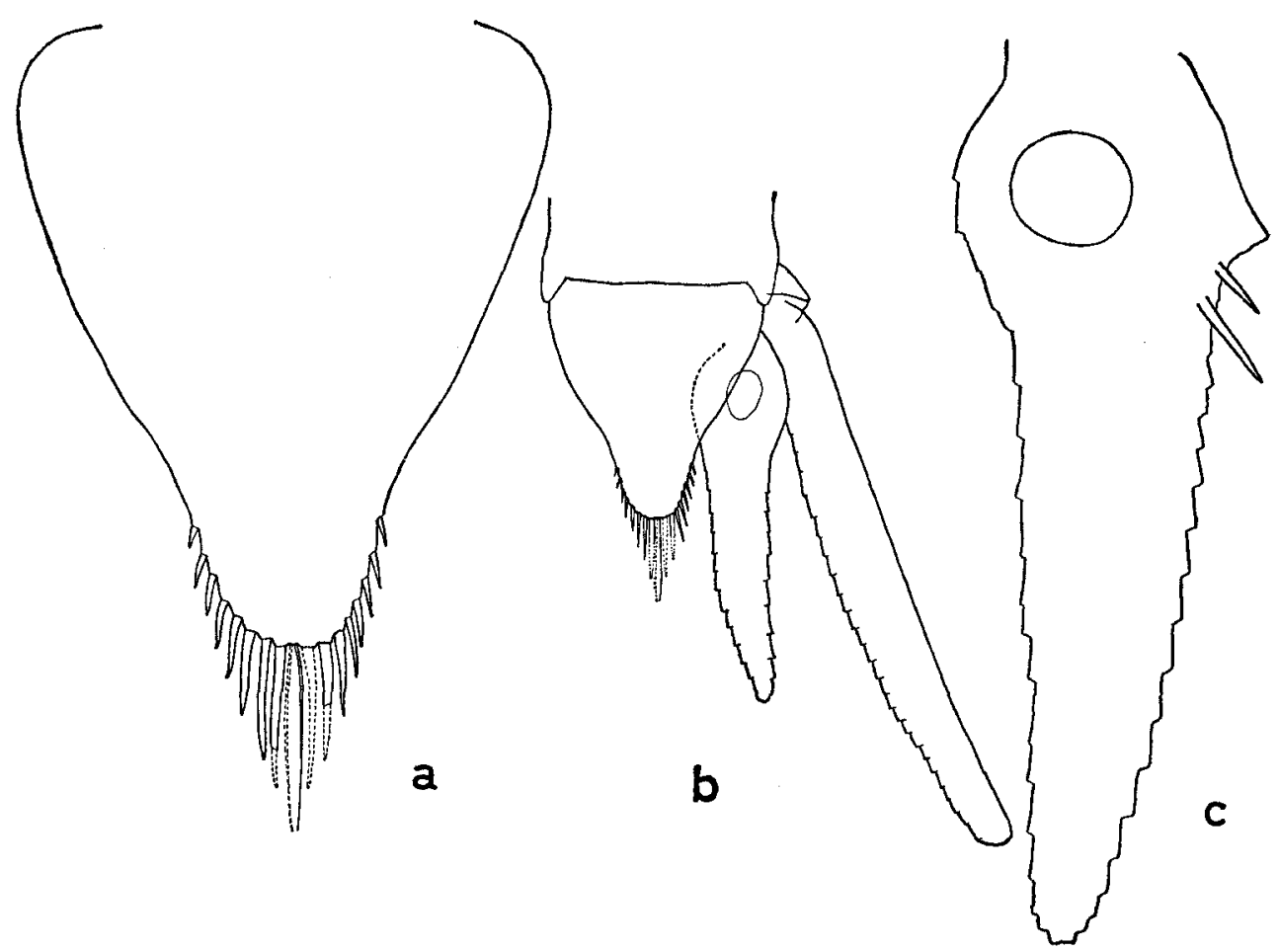

Fig. 6. Synerythrops intermedia Hansen; a, telson, $\times 42 ; b$, telson and uropod, $\times 17$; c, endopod of uropod, $\times 42$. 
$1 / 5$ of the scale.

Antennal peduncle is peculiar by reason of the fact that the third segment of the peduncle is connected with the distal end of the second segment on the ventral side near proximal end of the third segment (Fig. 5, b and c). As recorded by W. Tattersall in 1939, a small ocular papilla and 2 spines at statocyst region of the endopod of uropod are also present in the specimens from Japan (Fig. 5, a and Fis. 6, c).

Geographical distribution:

Although only three records from Manipa Strait of Indonesia, Gulf of Aden and Sagami and Suruga Bays of Central Japan have been known, it is suggested that this species widely distributed in the Indian Ocean and the western Pacific Ocean.

Vertical distribution:

The type specimen and the present one from St. $67-7$ were captured by a vertical haul from the depth of $1536 \mathrm{~m}$ to the surface and with an oblique haul from the depth of $1300 \mathrm{~m}$ to the surface, respectively, and so it is impossible to know the exact depths at which they were collected. While the specimen from the Gulf of Aden was collected with Agassiz Trawl from the depth of $620 \mathrm{~m}$. The present specimens from St. 202 and St. 533 were taken from the bottom of $480 \mathrm{~m}$ when the net accidentally came in touch with the bottom in an oblique haul and with the bottom-net from the depths of $570-660 \mathrm{~m}$, respectively. The species is surely a bottom-living form with a vertical distribution of the depth of about $500-600 \mathrm{~m}$.

\section{Synerythrops truncata sp. nov.}

(Figs. $4 \mathrm{~b}, 7$ and 8 )

Occurrence:

St. 293-2, 1 adult female (ca. $11.5 \mathrm{~mm}$ ).

St. 344,1 adult male $(10.0 \mathrm{~mm})$.

Description:

Carapace produced anteriorly, forming an acute-angled triangular rostral plate with an obtusely rounded tip, reaching to distal margin of first segment of antennular peduncle; antero-lateral corner of carapace rounded in dorsal view (Fig. 4, a and Fig. 7, b) ; posterior margin emarginate, leaving last thoracic somite exposed dorsally (Fig. 4, b). Eye moderate, globular and not depressed dorso-ventrally, reaching laterally to lateral line of anterior part of body; eyestalk shorter and narrower than cornea; papilla absent (Fig. 7, a). Antennular peduncle large and robust; first segment armed with a few plumose setae on its outer distal corner; second segment short, twice as wide as long; third segment long and stout, twice as long as broad (Fig. 4, b and Fig. 7, a). Antennal peduncle slender, somewhat shorter than antennular peduncle; first segment short, slightly longer than width; second segment about 1.5 times as long as broad, distal part of the segment becoming elongate and connecting with ventral side of basal part of third segment; third segment more slender and longer than second segment, more than twice as long as broad (Fig. 7, b and c). 
Antennal scale long, extending beyond antennular peduncle by $1 / 3$ of length of scale, nearly 5 times as long as broad; external margin straight, terminating into a relatively small spinous process which does not reach to apex of scale (Fig. 7b). Third segment of mandibular palp slender, furnished with short, stout, plumose setae on distal $3 / 4$ of inner margin (Fig. 7d). Maxilla somewhat slender, 1.5 times as long as broad; exopodite elliptical, about 3 times as long as broad; distal segment of endopod very short, only slightly longer than width (Fig. 7, f). First thoracic endopod short and

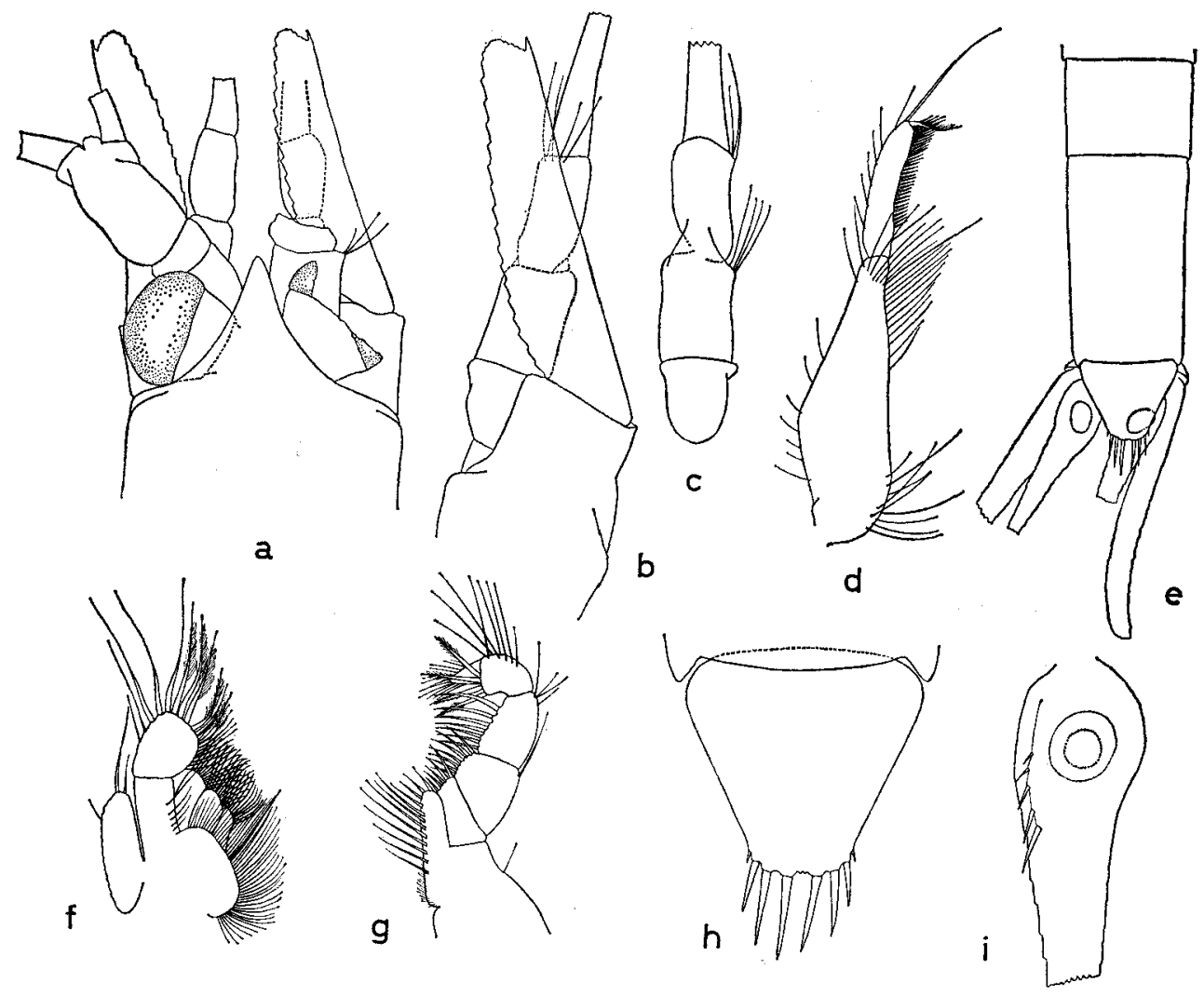

Fig. 7. Synerythrops truncata sp. nov.; a, anterior end of adult female, $\times 25 ; \mathrm{b}$, antennal peduncle and scale, $\times 31$; c, antennal scale in ventral view, $\times 31$; , mandibular palp, $\times 31$; e, posterior end of body, $\times 13$; f, maxilla, $\times 31$; g, endopod of first thoracic limb, $\times 31 ; \mathrm{h}$, telson, $\times 31$; i, basal half of endopod of uropod, $\times 31$.

robust; carpus, ischium and merus armed with stout setae on inner margins and propodus armed with 4 stout setae on its distal margin which is thicker than its basal margin (Fig. 7, g). Abdomen 6-segmented, first 5 segments subequal; sixth segment long, more than twice as long as fifth segment, slightly less than twice as long as wide (Fig. 4, b and Fig. 7, e). Male pleopods developed, biramous and natatory; endopods with short plate-like appendage not forming long narrow lobe as in $S$. intermedia; first pair with unsegmented endopod and 10-segmented exopod; second to fifth pairs 
subequal, about 11-segmented (Fig. 8, a, b and c). Telson very short, allied to that of genus Erythrops, nearly 1/3 of last abdominal somite in length, much shorter than width at base; distal margin rather truncate than rounded, furnished with 3 pairs of long spines which increase their length from outer pair to inner, longest pair of spines about 2/5 of length of telson, a pair of apical plumose setae damaged but maybe present originally; lateral margin nearly straight, only one or two small spines present at close distal end (Fig. 7, h and Fig. 8, d). Endopod of uropod very slender, some-

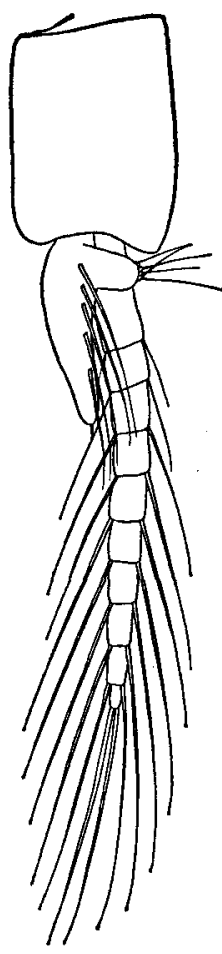

a

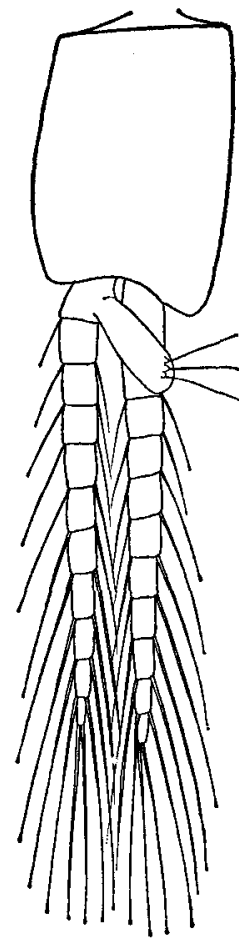

b
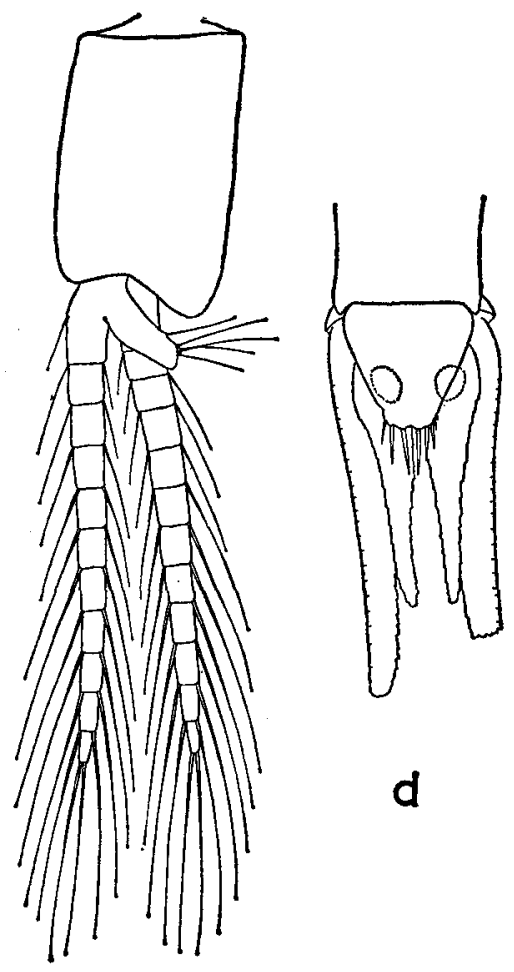

d

Fig. 8. Synerythrops truncata sp. nov.; $a$, first pleopod of male, $\times 40$; b, second pleopod of male, $\times 40$; , fourth pleopod of male, $\times 40$; , telson and uropod, $\times 16$.

what curved outwards, more than 3 times as long as telson; endopod shorter than exopod by $1 / 4$ of exopod, armed on ventral side near inner margin of statocyst region with 5 spines which become progressively longer distally (Fig. 7, e, i and Fig. 8, d). Types:

Holotype, adult female of ca. $11.8 \mathrm{~mm}$; allotype, adult male of $10.0 \mathrm{~mm}$. Remarks:

Only a couple of specimens were taken in the present collections. The specimens are easily recognized as belonging to genus Synerythrops in the long antennal scale, in 
the unusual connection between the second and third segments of antennal peduncle, in the short distal segment of endopod of maxilla and in the short telson.

The present species is distinguishable from two already known species, $S$. intermedia and $S$. cruciata, in the shape and armature of the telson. In the shape of the telson the present species is allied to the species of genus Erythrops, but, of cource, cannot be assigned to this genus in regard of the characteristics of eye, maxilla and so on.

The name truncata refers to the shape of telson.

The type specimens are lodged in Ocean Research Institute, University of Tokyo.

\section{REFERENCES}

Birstein, J.A. and J.G. Tchindonova, 1958. The deep-sea Mysidacea from north-western Pacific. Trudy Inst. Okeanol. AK. Nauk S.S.S.R., 27, 258-355.

Hansen, H.J., 1910. The Schizopoda of the Siboga Expedition. Siboga Monogr., 37: 1-123, pls. 1-16. , 1913. Report on the Crustacea Schizopoda collected by the Swedish Antarctic Expedition, 1901-03, under the charge of Baron Otto Nordenskjöld: 1-56, pls. I-6. (G.E.C. Gad, Copenhagen). - 1921. On some malacostracous Crustacea (Mysidacea, Euphausiacea, and Stomatopoda) collected by Swedish Antarctic Expeditions. Ark. Zool., 13, 1-7.

Ii, N., 1964. Fauna Japonica, Mysidac (Crustacea): i-x, 1-610, text-figs. 1-154. (Biogeograph. Soc. Japan, Tokyo).

Scientific members of the expedition, 1970. Preliminary report of the Hakuho Maru Cruise KH-69-4 (IBP Cruise), August 12-November 13, 1969, The North and Equatorial Pacific Ocean. Ocean Res. Inst., Univ. of Tokyo.

Sverdrup, H.U., M.W. Johnson and R.H. Fleming, 1942. The oceans, 1060 pp. (Prentice Hall, Inc., Englewood Cliffs).

Tattersall, W.M., 1936. Mysidacea and Euphausiacea. Sci. Rep. Gr. Barrier Recf Exped., 5: 143-176.

- 1939. The Euphausiacea and Mysidacea of the John Murray Expedition to the Indian Ocean. Sci. Rep. John Murray Exped., 5: 203-246. 1951. A review of the Mysidacea of the U.S. nation. Mus., 201: 1-292.

Zimmer, G., 1914. Die Schizopoden der deutschen Südpolar-Expedition 1901-03. Deutsche Südpolar-Exped. 1901-1903. 15 (Zool. 7): 377-445. 
Appendix-table 1. Tansei-Maru stations from which the collections reported here were taken.

\begin{tabular}{|c|c|c|c|c|c|c|c|c|c|}
\hline $\begin{array}{l}\text { Station } \\
\text { no. }\end{array}$ & & Date & & Ship time & & Position & & $\begin{array}{l}\text { Sampling } \\
\text { depth }(\mathrm{m})\end{array}$ & Net and remarks \\
\hline $6-5$ & Jan. & 24 , & 1964 & $16: 06-16: 54$ & $\begin{array}{r}\text { From } \\
\text { to }\end{array}$ & $\begin{array}{l}35^{\circ} 06.0^{\prime} \mathrm{N} \\
35^{\circ} 05.5^{\prime} \mathrm{N}\end{array}$ & $\begin{array}{l}139^{\circ} 19.0^{\prime} \mathrm{E} \\
139^{\circ} 19.4^{\prime} \mathrm{E}\end{array}$ & $0-720$ & ORI-net; oblique tow \\
\hline 53 & May & 21 , & 1964 & $13: 55-14: 47$ & $\begin{array}{r}\text { From } \\
\text { to }\end{array}$ & $\begin{array}{l}34^{\circ} 54.6^{\prime} \mathrm{N} \\
34^{\circ} 53.8^{\prime} \mathrm{N}\end{array}$ & $\begin{array}{l}139^{\circ} 23.2^{\prime} \mathrm{E} \\
139^{\circ} 23.3^{\prime} \mathrm{E}\end{array}$ & $0-715$ & ORI-net; oblique tow \\
\hline $67-5$ & Aug. & 16 & 1964 & $01: 14-02: 04$ & $\begin{array}{r}\text { From } \\
\text { to }\end{array}$ & $\begin{array}{l}34^{\circ} 52.8^{\prime} \mathrm{N} \\
34^{\circ} 54.5^{\prime} \mathrm{N}\end{array}$ & $\begin{array}{l}138^{\circ} 39.6^{\prime} \mathrm{E} \\
138^{\circ} 37.0^{\prime} \mathrm{E}\end{array}$ & $520-570$ & ORI-net; horizontal tow \\
\hline $67-7$ & Aug. & 16 & 1964 & $05: 30-06: 25$ & $\begin{array}{r}\text { From } \\
\text { to }\end{array}$ & $\begin{array}{l}34^{\circ} 53.3^{\prime} \mathrm{N} \\
34^{\circ} 52.2^{\prime} \mathrm{N}\end{array}$ & $\begin{array}{l}138^{\circ} 18.4^{\prime} \mathrm{E} \\
138^{\circ} 38.0^{\prime} \mathrm{E}\end{array}$ & $0-1300$ & ORI-net; oblique tow \\
\hline $76-2$ & Aug. & 18 & 1964 & $17: 50-20: 23$ & $\begin{array}{r}\text { From } \\
\text { to }\end{array}$ & $\begin{array}{l}34^{\circ} 34.4^{\prime} \mathrm{N} \\
34^{\circ} 28.2^{\prime} \mathrm{N}\end{array}$ & $\begin{array}{l}138^{\circ} 33.1^{\prime} \mathrm{E} \\
138^{\circ} 34.0^{\prime} \mathrm{E}\end{array}$ & $0-2300$ & ORI-net; oblique tow \\
\hline 77 & Aug. & 19 & 1964 & $00: 28-03: 10$ & $\begin{array}{r}\text { From } \\
\text { to }\end{array}$ & $\begin{array}{l}34^{\circ} 00.0^{\prime} \mathrm{N} \\
34^{\circ} 05.6^{\prime} \mathrm{N}\end{array}$ & $\begin{array}{l}138^{\circ} 19.6^{\prime} \mathrm{E} \\
138^{\circ} 18.0^{\prime} \mathrm{E}\end{array}$ & $0-1800$ & ORI-net; oblique tow \\
\hline 78 & Aug. & 19, & 1964 & $09: 40-11: 10$ & $\begin{array}{r}\text { From } \\
\text { to }\end{array}$ & $\begin{array}{l}34^{\circ} 15.5^{\prime} \mathrm{N} \\
34^{\circ} 15.0^{\prime} \mathrm{N}\end{array}$ & $\begin{array}{l}138^{\circ} 50.3^{\prime} \mathrm{E} \\
138^{\circ} 45.5^{\prime} \mathrm{E}\end{array}$ & $0-910$ & ORI-net; oblique tow \\
\hline 80 & Aug. & 20 , & 1964 & $01: 30-02: 37$ & $\begin{array}{r}\text { From } \\
\text { to }\end{array}$ & $\begin{array}{l}34^{\circ} 58.6^{\prime} \mathrm{N} \\
35^{\circ} 00.4^{\prime} \mathrm{N}\end{array}$ & $\begin{array}{l}139^{\circ} 19.2^{\prime} \mathrm{E} \\
139^{\circ} 18.3^{\prime} \mathrm{E}\end{array}$ & $0-1260$ & ORI-net; oblique tow \\
\hline 83 & Oct. & 23 & 1964 & $12: 22-14: 50$ & $\begin{array}{r}\text { From } \\
\text { to }\end{array}$ & $\begin{array}{l}34^{\circ} 51.4^{\prime} \mathrm{N} \\
34^{\circ} 50.1^{\prime} \mathrm{N}\end{array}$ & $\begin{array}{l}139^{\circ} 32.3^{\prime} \mathrm{E} \\
139^{\circ} 28.1^{\prime} \mathrm{E}\end{array}$ & $0-1260$ & ORI-net, oblique tow \\
\hline $84-3$ & Oct. & 25 & 1964 & $16: 34-17: 45$ & $\begin{array}{r}\text { From } \\
\text { to }\end{array}$ & $\begin{array}{l}35^{\circ} 06.3^{\prime} \mathrm{N} \\
35^{\circ} 04.4^{\prime} \mathrm{N}\end{array}$ & $\begin{array}{l}139^{\circ} 17.0^{\prime} \mathrm{E} \\
139^{\circ} 17.2^{\prime} \mathrm{E}\end{array}$ & $0-1000$ & $\begin{array}{l}\text { ORI-net, accidentally touched } \\
\text { the sea-floor in oblique tow }\end{array}$ \\
\hline $93-2$ & Oct. & 28 & 1964 & $12: 28-13: 35$ & $\begin{array}{r}\text { From } \\
\text { to }\end{array}$ & $\begin{array}{l}34^{\circ} 55.4^{\prime} \mathrm{N} \\
34^{\circ} 56.1^{\prime} \mathrm{N}\end{array}$ & $\begin{array}{l}138^{\circ} 38.7^{\prime} \mathrm{E} \\
138^{\circ} 38.3^{\prime} \mathrm{E}\end{array}$ & $0-1300$ & ORI-net, oblique tow \\
\hline 94 & Oct. & 31 , & 1964 & $14: 55-16: 03$ & $\begin{array}{r}\text { From } \\
\text { to }\end{array}$ & $\begin{array}{l}34^{\circ} 30.0^{\prime} \mathrm{N} \\
34^{\circ} 27.9^{\prime} \mathrm{N}\end{array}$ & $\begin{array}{l}138^{\circ} 29.7^{\prime} \mathrm{E} \\
138^{\circ} 29.6^{\prime} \mathrm{E}\end{array}$ & $0-1020$ & ORI-net, oblique tow \\
\hline 95 & Oct. & 31, & 1964 & $18: 09-19: 17$ & $\begin{array}{r}\text { From } \\
\text { to }\end{array}$ & $\begin{array}{l}34^{\circ} 10.1^{\prime} \mathrm{N} \\
34^{\circ} 06.9^{\prime} \mathrm{N}\end{array}$ & $\begin{array}{l}139^{\circ} 29.0^{\prime} \mathrm{E} \\
139^{\circ} 29.0^{\prime} \mathrm{E}\end{array}$ & $0-1120$ & ORI-net, oblique tow \\
\hline 1042 & Mar. & 1, & 1965 & $11: 39-12: 55$ & $\begin{array}{r}\text { From } \\
\text { to }\end{array}$ & $\begin{array}{l}35^{\circ} 05.2^{\prime} \mathrm{N} \\
35^{\circ} 02.9^{\prime} \mathrm{N}\end{array}$ & $\begin{array}{l}139^{\circ} 17.0^{\prime} \mathrm{E} \\
139^{\circ} 16.8^{\prime} \mathrm{E}\end{array}$ & $0-1300$ & $\begin{array}{l}\text { ORI-net, accidentally touched } \\
\text { the sea-floor in oblique tow }\end{array}$ \\
\hline $104-6$ & Mar. & 1 , & 1965 & $16: 10-17: 10$ & $\begin{array}{r}\text { From } \\
\text { to }\end{array}$ & $\begin{array}{l}35^{\circ} 06.7^{\prime} \mathrm{N} \\
35^{\circ} 05.3^{\prime} \mathrm{N}\end{array}$ & $\begin{array}{l}139^{\circ} 16.9^{\prime} \mathrm{E} \\
139^{\circ} 17.1^{\prime} \mathrm{E}\end{array}$ & $670-800$ & ORI-net, horizontal tow \\
\hline
\end{tabular}


Appendix-table 1. (Cont.)

\begin{tabular}{|c|c|c|c|c|c|c|c|c|c|}
\hline $\begin{array}{l}\text { Station } \\
\text { no. }\end{array}$ & & Date & & Ship time & & Position & & $\begin{array}{l}\text { Sampling } \\
\text { depth (m) }\end{array}$ & Net and remarks \\
\hline $104-8$ & Mar. & 1 , & 1965 & $20: 12-21: 03$ & $\begin{array}{r}\text { From } \\
\text { to }\end{array}$ & $\begin{array}{l}34^{\circ} 59.3^{\prime} \mathrm{N} \\
35^{\circ} 00.2^{\prime} \mathrm{N}\end{array}$ & $\begin{array}{l}139^{\circ} 15.9^{\prime} \mathrm{E} \\
139^{\circ} 15.5^{\prime} \mathrm{E}\end{array}$ & $0-1100$ & ORI-net, oblique tow \\
\hline 107 & Mar. & 4, & 1965 & $11: 33-14: 27$ & $\begin{array}{r}\text { From } \\
\text { to }\end{array}$ & $\begin{array}{l}34^{\circ} 32.6^{\prime} \mathrm{N} \\
34^{\circ} 26.0^{\prime} \mathrm{N}\end{array}$ & $\begin{array}{l}138^{\circ} 35.4^{\prime} \mathrm{E} \\
138^{\circ} 35.6^{\prime} \mathrm{E}\end{array}$ & $0-2000$ & ORI-net, oblique tow \\
\hline 108 & Apr. & 23 & 1965 & $12: 12-13: 30$ & $\begin{array}{r}\text { From } \\
\text { to }\end{array}$ & $\begin{array}{l}35^{\circ} 04.9^{\prime} \mathrm{N} \\
35^{\circ} 02.1^{\prime} \mathrm{N}\end{array}$ & $\begin{array}{l}139^{\circ} 19.6^{\prime} \mathrm{E} \\
139^{\circ} 18.9^{\prime} \mathrm{E}\end{array}$ & $0-1000$ & ORI-net, oblique tow \\
\hline 110 & Apr. & 23 & 1965 & $19: 07-20: 24$ & $\begin{array}{r}\text { From } \\
\text { to }\end{array}$ & $\begin{array}{l}34^{\circ} 49.9^{\prime} \mathrm{N} \\
34^{\circ} 49.6^{\prime} \mathrm{N}\end{array}$ & $\begin{array}{l}139^{\circ} 31.6^{\prime} \mathrm{E} \\
139^{\circ} 28.8^{\prime} \mathrm{E}\end{array}$ & $0-1440$ & ORI-net, oblique tow \\
\hline $111-2$ & Apr. & 24 & 1965 & $16: 05-18: 59$ & $\begin{array}{r}\text { From } \\
\text { to }\end{array}$ & $\begin{array}{l}34^{\circ} 31.2^{\prime} \mathrm{N} \\
34^{\circ} 23.6^{\prime} \mathrm{N}\end{array}$ & $\begin{array}{l}138^{\circ} 33.7^{\prime} \mathrm{E} \\
138^{\circ} 34.6^{\prime} \mathrm{E}\end{array}$ & $0-1430$ & ORI-net, oblique tow \\
\hline 112 & Apr. & 24 & 1965 & $22: 24-23: 43$ & $\begin{array}{r}\text { From } \\
\text { to }\end{array}$ & $\begin{array}{l}34^{\circ} 00.0^{\prime} \mathrm{N} \\
33^{\circ} 55.0^{\prime} \mathrm{N}\end{array}$ & $\begin{array}{l}138^{\circ} 28.0^{\prime} \mathrm{E} \\
138^{\circ} 27.0^{\prime} \mathrm{E}\end{array}$ & $0-1300$ & ORI-net, oblique tow \\
\hline 114 & Apr. & 25 & 1965 & $07: 43-09: 00$ & $\begin{array}{r}\text { From } \\
\text { to }\end{array}$ & $\begin{array}{l}33^{\circ} 01.2^{\prime} \mathrm{N} \\
33^{\circ} 01.2^{\prime} \mathrm{N}\end{array}$ & $\begin{array}{l}138^{\circ} 33.5^{\prime} \mathrm{E} \\
138^{\circ} 38.0^{\prime} \mathrm{E}\end{array}$ & $0-930$ & ORI-net, oblique tow \\
\hline $115-2$ & Apr. & 25 & 1965 & $13: 47-16: 39$ & $\begin{array}{r}\text { From } \\
\text { to }\end{array}$ & $\begin{array}{l}32^{\circ} 31.1^{\prime} \mathrm{N} \\
32^{\circ} 26.5^{\prime} \mathrm{N}\end{array}$ & $\begin{array}{l}138^{\circ} 40.2^{\prime} \mathrm{E} \\
138^{\circ} 36.7^{\prime} \mathrm{E}\end{array}$ & $0-2500$ & ORI-net, oblique tow \\
\hline 118 & Apr. & 26 & 1965 & $11: 27-12: 40$ & $\begin{array}{r}\text { From } \\
\text { to }\end{array}$ & $\begin{array}{l}33^{\circ} 01.2^{\prime} \mathrm{N} \\
33^{\circ} 03.7^{\prime} \mathrm{N}\end{array}$ & $\begin{array}{l}140^{\circ} 30.0^{\prime} \mathrm{E} \\
140^{\circ} 31.5^{\prime} \mathrm{E}\end{array}$ & $0-1250$ & $\begin{array}{l}\text { ORI-net, accidentally touched } \\
\text { the sea-floor in oblique tow }\end{array}$ \\
\hline 120 & Apr. & 26 & 1965 & $19: 30-20: 49$ & $\begin{array}{r}\text { From } \\
\text { to }\end{array}$ & $\begin{array}{l}34^{\circ} 01.0^{\prime} \mathrm{N} \\
34^{\circ} 03.3^{\prime} \mathrm{N}\end{array}$ & $\begin{array}{l}140^{\circ} 30.0^{\prime} \mathrm{E} \\
140^{\circ} 31.1^{\prime} \mathrm{E}\end{array}$ & $0-1000$ & ORI-net, oblique tow \\
\hline $121-2$ & Apr. & 27 & 1965 & $01: 20-04: 20$ & $\begin{array}{r}\text { From } \\
\text { to }\end{array}$ & $\begin{array}{l}34^{\circ} 33.3^{\prime} \mathrm{N} \\
34^{\circ} 35.0^{\prime} \mathrm{N}\end{array}$ & $\begin{array}{l}140^{\circ} 35.0^{\prime} \mathrm{E} \\
140^{\circ} 47.0^{\prime} \mathrm{E}\end{array}$ & $0-1100$ & ORI-net, oblique tow \\
\hline $128-5$ & July & 14, & 1965 & $05: 08-06: 08$ & $\begin{array}{r}\text { From } \\
\text { to }\end{array}$ & $\begin{array}{l}34^{\circ} 53.8^{\prime} \mathrm{N} \\
34^{\circ} 51.1^{\prime} \mathrm{N}\end{array}$ & $\begin{array}{l}138^{\circ} 37.8^{\prime} \mathrm{E} \\
138^{\circ} 38.0^{\prime} \mathrm{E}\end{array}$ & ca. 1000 & ORI-net, horizontal tow \\
\hline 138 & Apr. & 19 & 1966 & $13: 43-14: 55$ & $\begin{array}{r}\text { From } \\
\text { to }\end{array}$ & $\begin{array}{l}35^{\circ} 00.6^{\prime} \mathrm{N} \\
35^{\circ} 02.8^{\prime} \mathrm{N}\end{array}$ & $\begin{array}{l}139^{\circ} 15.1^{\prime} \mathrm{E} \\
139^{\circ} 15.6^{\prime} \mathrm{E}\end{array}$ & - & ORI-net, oblique tow \\
\hline 139 & Apr. & 20 & 1966 & $09: 25-10: 39$ & $\begin{array}{r}\text { From } \\
\text { to }\end{array}$ & $\begin{array}{l}35^{\circ} 04.9^{\prime} \mathrm{N} \\
35^{\circ} 03.5^{\prime} \mathrm{N}\end{array}$ & $\begin{array}{l}139^{\circ} 22.2^{\prime} \mathrm{E} \\
139^{\circ} 25.1^{\prime} \mathrm{E}\end{array}$ & $0-850$ & ORI-net, oblique tow \\
\hline $144-3$ & June & 11 & 1966 & $00: 23-03: 15$ & $\begin{array}{r}\text { From } \\
\text { to }\end{array}$ & $\begin{array}{l}27^{\circ} 57.5^{\prime} \mathrm{N} \\
27^{\circ} 51.2^{\prime} \mathrm{N}\end{array}$ & $\begin{array}{l}131^{\circ} 56.4^{\prime} \mathrm{E} \\
131^{\circ} 56.8^{\prime} \mathrm{E}\end{array}$ & $0-800$ & ORI-net, oblique tow \\
\hline
\end{tabular}


Appendix-table 1. (Cont.)

\begin{tabular}{|c|c|c|c|c|c|c|c|c|}
\hline $\begin{array}{l}\text { Station } \\
\text { no. }\end{array}$ & & Date & & Ship time & Positio & & $\begin{array}{l}\text { Sampling } \\
\text { depth (m) }\end{array}$ & Net and remarks \\
\hline $145-4$ & June & 12 & 1966 & $15: 50-18: 39$ & $\begin{array}{r}\text { From } 28^{\circ} 03.9^{\prime} \mathrm{N}, \\
\text { to } 28^{\circ} 08.5^{\prime} \mathrm{N} \text {, }\end{array}$ & $\begin{array}{l}135^{\circ} 44.3^{\prime} \mathrm{E} \\
135^{\circ} 46.4^{\prime} \mathrm{E}\end{array}$ & $0-750$ & ORI-net, oblique tow \\
\hline $146-4$ & June & 13 & 1966 & $17: 50-21: 00$ & $\begin{array}{r}\text { From } 30^{\circ} 08.1^{\prime} \mathrm{N}, \\
\text { to } 30^{\circ} 10.5^{\prime} \mathrm{N},\end{array}$ & $\begin{array}{l}135^{\circ} 49.2^{\prime} \mathrm{E} \\
135^{\circ} 49.7^{\prime} \mathrm{E}\end{array}$ & $?-1374-?$ & ORI-net, horizontal tow \\
\hline 152 & July & 14 , & 1966 & $14: 35-16: 10$ & $\begin{array}{r}\text { From } 34^{\circ} 56.7^{\prime} \mathrm{N}, \\
\text { to } 34^{\circ} 53.0^{\prime} \mathrm{N},\end{array}$ & $\begin{array}{l}138^{\circ} 38.6^{\prime} \mathrm{E} \\
138^{\circ} 39.8^{\prime} \mathrm{E}\end{array}$ & $0-1000$ & ORI-net, oblique tow \\
\hline 154 & July & 15 & 1966 & $00: 50-02: 39$ & $\begin{array}{r}\text { From } 34^{\circ} 53.4^{\prime} \mathrm{N} \text {, } \\
\text { to } 34^{\circ} 57.2^{\prime} \mathrm{N} \text {, }\end{array}$ & $\begin{array}{l}138^{\circ} 38.8^{\prime} \mathrm{E} \\
138^{\circ} 40.0^{\prime} \mathrm{E}\end{array}$ & $0-950$ & ORI-net, oblique tow \\
\hline 155 & July & 15 & 1966 & $02: 45-04: 30$ & $\begin{array}{r}\text { From } 34^{\circ} 57.2^{\prime} \mathrm{N}, \\
\text { to } 34^{\circ} 52.9^{\prime} \mathrm{N},\end{array}$ & $\begin{array}{l}138^{\circ} 40.0^{\prime} \mathrm{E} \\
138^{\circ} 37.8^{\prime} \mathrm{E}\end{array}$ & $0-820$ & ORI-net, oblique tow \\
\hline $156-1$ & July & 15 & 1966 & $17: 00-18: 46$ & $\begin{array}{r}\text { From } 34^{\circ} 32.3^{\prime} \mathrm{N} \text {, } \\
\text { to } 34^{\circ} 35.5^{\prime} \mathrm{N} \text {, }\end{array}$ & $\begin{array}{l}138^{\circ} 35.6^{\prime} \mathrm{E} \\
138^{\circ} 36.6^{\prime} \mathrm{E}\end{array}$ & $0-1000$ & ORI-net, oblique tow \\
\hline 157 & July & 15 & 1966 & $19: 53-21: 38$ & $\begin{array}{r}\text { From } 34^{\circ} 25.7^{\prime} \mathrm{N}, \\
\text { to } 34^{\circ} 23.1^{\prime} \mathrm{N},\end{array}$ & $\begin{array}{l}138^{\circ} 37.2^{\prime} \mathrm{E} \\
138^{\circ} 34.5^{\prime} \mathrm{E}\end{array}$ & $0-1000$ & ORI-net, oblique tow \\
\hline $158-1$ & July & 15 & 1966 & $21: 43-23: 26$ & $\begin{array}{r}\text { From } 34^{\circ} 23.0^{\prime} \mathrm{N}, \\
\text { to } 34^{\circ} 22.0^{\prime} \mathrm{N},\end{array}$ & $\begin{array}{l}138^{\circ} 34.4^{\prime} \mathrm{E} \\
138^{\circ} 30.3^{\prime} \mathrm{E}\end{array}$ & $0-900$ & ORI-net, oblique tow \\
\hline 159 & July 1 & $5-16$, & 1966 & $23: 35-01: 20$ & $\begin{array}{r}\text { From } 34^{\circ} 22.3^{\prime} \mathrm{N}, \\
\text { to } 34^{\circ} 24.2^{\prime} \mathrm{N},\end{array}$ & $\begin{array}{l}138^{\circ} 30.0^{\prime} \mathrm{E} \\
138^{\circ} 32.2^{\prime} \mathrm{E}\end{array}$ & $0-1300$ & ORI-net, oblique tow \\
\hline 160 & July & 16 & 1966 & $01: 25-03: 05$ & $\begin{array}{r}\text { From } 34^{\circ} 24.4^{\prime} \mathrm{N}, \\
\text { to } 34^{\circ} 27.4^{\prime} \mathrm{N},\end{array}$ & $\begin{array}{l}138^{\circ} 32.5^{\prime} \mathrm{E} \\
138^{\circ} 32.6^{\prime} \mathrm{E}\end{array}$ & $0-930$ & ORI-net, oblique tow \\
\hline 161 & July & 16 & 1966 & $03: 14-05: 00$ & $\begin{array}{r}\text { From } 34^{\circ} 27.4^{\prime} \mathrm{N}, \\
\text { to } 34^{\circ} 29.2^{\prime} \mathrm{N},\end{array}$ & $\begin{array}{l}138^{\circ} 32.6^{\prime} \mathrm{E} \\
138^{\circ} 36.9^{\prime} \mathrm{E}\end{array}$ & $0-850$ & ORI-net, oblique tow \\
\hline $169-3$ & July & 17 & 1966 & $21: 48-22: 48$ & $\begin{array}{r}\text { From } 34^{\circ} 28.9^{\prime} \mathrm{N}, \\
\text { to } 34^{\circ} 27.5^{\prime} \mathrm{N},\end{array}$ & $\begin{array}{l}138^{\circ} 37.0^{\prime} \mathrm{E} \\
138^{\circ} 35.4^{\prime} \mathrm{E}\end{array}$ & $420-700$ & ORI-net, horizontal tow \\
\hline $169-4$ & July 1 & $7-18$ & 1966 & $23: 53-01: 23$ & $\begin{array}{r}\text { From } 34^{\circ} 26.8^{\prime} \mathrm{N}, \\
\text { to } 34^{\circ} 25.8^{\prime} \mathrm{N},\end{array}$ & $\begin{array}{l}138^{\circ} 34.6^{\prime} \mathrm{E} \\
138^{\circ} 30.7^{\prime} \mathrm{E}\end{array}$ & $800-1300$ & ORI-net, horizontal tow \\
\hline $176-6$ & July & 19 & 1966 & $03: 08-04: 38$ & $\begin{array}{r}\text { From } 34^{\circ} 49.5^{\prime} \mathrm{N}, \\
\text { to } 34^{\circ} 47.4^{\prime} \mathrm{N},\end{array}$ & $\begin{array}{l}139^{\circ} 34.4^{\prime} \mathrm{E} \\
139^{\circ} 35.9^{\prime} \mathrm{E}\end{array}$ & $550-1200$ & ORI-net, horizontal tow \\
\hline $177-5$ & July & 19 & 1966 & $19: 28-20: 58$ & $\begin{array}{r}\text { From } 34^{\circ} 48.3^{\prime} \mathrm{N} \text {, } \\
\text { to } 34^{\circ} 45.5^{\prime} \mathrm{N} \text {, }\end{array}$ & $\begin{array}{l}139^{\circ} 31.6^{\prime} \mathrm{E} \\
139^{\circ} 31.5^{\prime} \mathrm{E}\end{array}$ & $700-770$ & ORI-net, horizontal tow \\
\hline
\end{tabular}


Appendix-table 1. (Cont.)

\begin{tabular}{|c|c|c|c|c|c|c|c|c|c|}
\hline $\begin{array}{l}\text { Station } \\
\text { no. }\end{array}$ & & Date & & Ship time & & Position & & $\begin{array}{l}\text { Sampling } \\
\text { depth }(m)\end{array}$ & Net and remarks \\
\hline $177-6$ & July & 20 & 1966 & $05: 05-06: 35$ & $\begin{array}{r}\text { From } \\
\text { to }\end{array}$ & $\begin{array}{l}34^{\circ} 43.3^{\prime} \mathrm{N} \\
34^{\circ} 45.9^{\prime} \mathrm{N}\end{array}$ & $\begin{array}{l}139^{\circ} 35.9^{\prime} \mathrm{E} \\
139^{\circ} 35.4^{\prime} \mathrm{E}\end{array}$ & $1350-1500$ & ORI-net, horizontal tow \\
\hline $179-4$ & July & 21 & 1966 & $00: 28-01: 28$ & $\begin{array}{r}\text { From } \\
\text { to }\end{array}$ & $\begin{array}{l}34^{\circ} 45.1^{\prime} \mathrm{N} \\
34^{\circ} 43.6^{\prime} \mathrm{N}\end{array}$ & $\begin{array}{l}139^{\circ} 31.4^{\prime} \mathrm{E} \\
139^{\circ} 32.8^{\prime} \mathrm{E}\end{array}$ & $400-600$ & ORI-net, horizontal tow \\
\hline $179-6$ & July & 21 & 1966 & $06: 08-07: 43$ & $\begin{array}{r}\text { From } \\
\text { to }\end{array}$ & $\begin{array}{l}34^{\circ} 44.9^{\prime} \mathrm{N} \\
34^{\circ} 42.3^{\prime} \mathrm{N}\end{array}$ & $\begin{array}{l}139^{\circ} 36.2^{\prime} \mathrm{E} \\
139^{\circ} 37.8^{\prime} \mathrm{E}\end{array}$ & $700-1000$ & ORI-net, horizontal tow \\
\hline $180-4$ & July & 21, & 1966 & $12: 25-13: 30$ & $\begin{array}{r}\text { From } \\
\text { to }\end{array}$ & $\begin{array}{l}34^{\circ} 43.6^{\prime} \mathrm{N} \\
34^{\circ} 44.0^{\prime} \mathrm{N}\end{array}$ & $\begin{array}{l}139^{\circ} 36.5^{\prime} \mathrm{E} \\
139^{\circ} 34.2^{\prime} \mathrm{E}\end{array}$ & $500-850$ & ORI-net, horizontal tow \\
\hline 182 & July & 23 & 1966 & $05: 35-06: 48$ & $\begin{array}{r}\text { From } \\
\text { to }\end{array}$ & $\begin{array}{l}34^{\circ} 49.6^{\prime} \mathrm{N} \\
34^{\circ} 47.5^{\prime} \mathrm{N}\end{array}$ & $\begin{array}{l}139^{\circ} 31.9^{\prime} \mathrm{E} \\
139^{\circ} 32.1^{\prime} \mathrm{E}\end{array}$ & $0-1150$ & ORI-net, oblique tow \\
\hline 185 & July & 24 & 1966 & $05: 44-08: 01$ & $\begin{array}{r}\text { From } \\
\text { to }\end{array}$ & $\begin{array}{l}34^{\circ} 41.0^{\prime} \mathrm{N} \\
34^{\circ} 44.2^{\prime} \mathrm{N}\end{array}$ & $\begin{array}{l}139^{\circ} 38.8^{\prime} \mathrm{E} \\
139^{\circ} 36.5^{\prime} \mathrm{E}\end{array}$ & $0-2000$ & ORI-net, oblique tow \\
\hline $190-7$ & Sep. & 22 & 1966 & $02: 04-03: 12$ & $\begin{array}{r}\text { From } \\
\text { to }\end{array}$ & $\begin{array}{l}39^{\circ} 03.5^{\prime} \mathrm{N} \\
39^{\circ} 01.5^{\prime} \mathrm{N}\end{array}$ & $\begin{array}{l}144^{\circ} 21.4^{\prime} \mathrm{E} \\
144^{\circ} 22.5^{\prime} \mathrm{E}\end{array}$ & $0-1060$ & ORI-net, oblique tow \\
\hline 192 & Sep. & 27 & 1966 & $18: 58-19: 49$ & $\begin{array}{r}\text { From } \\
\text { to }\end{array}$ & $\begin{array}{l}39^{\circ} 40.8^{\prime} \mathrm{N} \\
39^{\circ} 39.0^{\prime} \mathrm{N}\end{array}$ & $\begin{array}{l}142^{\circ} 39.9^{\prime} \mathrm{E} \\
142^{\circ} 39.7^{\prime} \mathrm{E}\end{array}$ & $0-900$ & ORI-net, oblique tow \\
\hline $194-2$ & Sep. & 29 & 1966 & $16: 49-18: 07$ & $\begin{array}{r}\text { From } \\
\text { to }\end{array}$ & $\begin{array}{l}37^{\circ} 51.0^{\prime} \mathrm{N} \\
37^{\circ} 49.0^{\prime} \mathrm{N}\end{array}$ & $\begin{array}{l}142^{\circ} 38.3^{\prime} \mathrm{E} \\
142^{\circ} 42.0^{\prime} \mathrm{E}\end{array}$ & $0-980$ & ORI-net, oblique tow \\
\hline $196-2$ & Oct. & 1, & 1966 & $00: 18-02: 47$ & $\begin{array}{r}\text { From } \\
\text { to }\end{array}$ & $\begin{array}{l}36^{\circ} 06.2^{\prime} \mathrm{N} \\
36^{\circ} 03.3^{\prime} \mathrm{N}\end{array}$ & $\begin{array}{l}142^{\circ} 20.2^{\prime} \mathrm{E} \\
142^{\circ} 15.5^{\prime} \mathrm{E}\end{array}$ & $0-2100$ & ORI-net, oblique tow \\
\hline $197-1$ & Oct. & 1, & 1966 & $09: 55-11: 05$ & $\begin{array}{r}\text { From } \\
\text { to }\end{array}$ & $\begin{array}{l}35^{\circ} 15.8^{\prime} \mathrm{N} \\
35^{\circ} 17.2^{\prime} \mathrm{N}\end{array}$ & $\begin{array}{l}142^{\circ} 23.2^{\prime} \mathrm{E} \\
142^{\circ} 20.3^{\prime} \mathrm{E}\end{array}$ & $0-750$ & ORI-net, oblique tow \\
\hline $197-2$ & Oct. & 1, & 1966 & $11: 12-13: 36$ & $\begin{array}{r}\text { From } \\
\text { to }\end{array}$ & $\begin{array}{l}35^{\circ} 17.2^{\prime} \mathrm{N} \\
35^{\circ} 18.6^{\prime} \mathrm{N}\end{array}$ & $\begin{array}{l}142^{\circ} 20.3^{\prime} \mathrm{E} \\
142^{\circ} 13.0^{\prime} \mathrm{E}\end{array}$ & $0-2270$ & ORI-net, oblique tow \\
\hline 200 & Oct. & 17 & 1966 & $21: 45-22: 53$ & & $33^{\circ} 55.3^{\prime} \mathrm{N}$ & $137^{\circ} 27.4^{\prime} \mathrm{E}$ & $0-1350$ & ORI-net, oblique tow \\
\hline 202 & Oct. & 18 , & 1966 & $14: 49-15: 21$ & & $34^{\circ} 44.8^{\prime} \mathrm{N}$ & $139^{\circ} 08.5^{\prime} \mathrm{E}$ & $0-480$ & $\begin{array}{l}\text { ORI-net, accidentally touched } \\
\text { the sea-floor in oblique tow }\end{array}$ \\
\hline 206 & Jan. & 18 , & 1967 & $18: 42-19: 50$ & $\begin{array}{r}\text { From } \\
\text { to }\end{array}$ & $\begin{array}{l}35^{\circ} 10.2^{\prime} \mathrm{N} \\
35^{\circ} 07.9^{\prime} \mathrm{N}\end{array}$ & $\begin{array}{l}139^{\circ} 16.3^{\prime} \mathrm{E} \\
139^{\circ} 16.8^{\prime} \mathrm{E}\end{array}$ & $0-950$ & ORI-net, oblique tow \\
\hline
\end{tabular}


Appendix-table 1. (Cont.)

\begin{tabular}{|c|c|c|c|c|c|c|c|c|}
\hline $\begin{array}{l}\text { Station } \\
\text { no. }\end{array}$ & & Date & & Ship time & Position & & $\begin{array}{l}\text { Sampling } \\
\text { depth }(\mathrm{m})\end{array}$ & Net and remarks \\
\hline 213 & Jan. & 19 & 1967 & $09: 13-10: 21$ & $\begin{array}{r}\text { From } 34^{\circ} 59.8^{\prime} \mathrm{N}, \\
\text { to } 34^{\circ} 59.6^{\prime} \mathrm{N} \text {, }\end{array}$ & $\begin{array}{l}139^{\circ} 22.8^{\prime} \mathrm{E} \\
139^{\circ} 20.3^{\prime} \mathrm{E}\end{array}$ & $0-850$ & ORI-net, oblique tow \\
\hline $224-6$ & Apr. : & 24-25, & 1967 & $22: 26-00: 09$ & $\begin{array}{r}\text { From } 34^{\circ} 41.1^{\prime} \mathrm{N}, \\
\text { to } 34^{\circ} 39.4^{\prime} \mathrm{N},\end{array}$ & $\begin{array}{l}139^{\circ} 59.3^{\prime} \mathrm{E} \\
139^{\circ} 58.6^{\prime} \mathrm{E}\end{array}$ & $600-1170$ & ORI-net, horizontal tow \\
\hline $224-10$ & Apr. & 25 & 1967 & $02: 00-04: 03$ & $\begin{array}{r}\text { From } 34^{\circ} 43.4^{\prime} \mathrm{N}, \\
\text { to } 34^{\circ} 42.7^{\prime} \mathrm{N} \text {, }\end{array}$ & $\begin{array}{l}140^{\circ} 01.0^{\prime} \mathrm{E} \\
139^{\circ} 59.8^{\prime} \mathrm{E}\end{array}$ & $650-1450$ & ORI-net, horizontal tow \\
\hline $225-9$ & Apr. & 25 & 1967 & $13: 51-15: 36$ & $\begin{array}{r}\text { From } 34^{\circ} 41.0^{\prime} \mathrm{N}, \\
\text { to } 34^{\circ} 39.7^{\prime} \mathrm{N} \text {, }\end{array}$ & $\begin{array}{l}139^{\circ} 57.2^{\prime} \mathrm{E} \\
139^{\circ} 57.3^{\prime} \mathrm{E}\end{array}$ & $475-1000$ & ORI-net, horizontal tow \\
\hline $225-10$ & Apr. & 25 & 1967 & $15: 45-18: 20$ & $\begin{array}{r}\text { From } 34^{\circ} 41.2^{\prime} \mathrm{N}, \\
\text { to } 34^{\circ} 44.7^{\prime} \mathrm{N},\end{array}$ & $\begin{array}{l}139^{\circ} 59.7^{\prime} \mathbf{E} \\
140^{\circ} 01.5^{\prime} \mathrm{E}\end{array}$ & $520-700$ & ORI-net, horizontal tow \\
\hline 228 & Apr. 2 & 25-26, & 1967 & $23: 15-01: 02$ & $\begin{array}{r}\text { From } 34^{\circ} 42.0^{\prime} \mathrm{N}, \\
\text { to } 34^{\circ} 42.0^{\prime} \mathrm{N},\end{array}$ & $\begin{array}{l}140^{\circ} 02.5^{\prime} \mathrm{E} \\
140^{\circ} 00.0^{\prime} \mathrm{E}\end{array}$ & $550-1150$ & ORI-net, horizontal tow \\
\hline $258-11$ & Aug. & 1, & 1967 & $03: 30-05: 30$ & $\begin{array}{l}\text { From } 42^{\circ} 20.8^{\prime} \mathrm{N}, \\
\text { to } 42^{\circ} 19.7^{\prime} \mathrm{N} \text {, }\end{array}$ & $\begin{array}{l}144^{\circ} 54.1^{\prime} \mathbf{E} \\
144^{\circ} 56.9^{\prime} \mathbf{E}\end{array}$ & $1550-1750$ & ORI-net, horizontal tow \\
\hline $293-2$ & Apr. & 13, & 1968 & $13: 00-13: 37$ & $\begin{array}{r}\text { From } 35^{\circ} 00.3^{\prime} \mathrm{N}, \\
\text { to } 35^{\circ} 00.0^{\prime} \mathrm{N},\end{array}$ & $\begin{array}{l}139^{\circ} 48.4^{\prime} \mathrm{E} \\
139^{\circ} 47.6^{\prime} \mathbf{E}\end{array}$ & $220-330$ & Bottom-net \\
\hline 313 & Nov. & 3 , & 1968 & $22: 18-22: 33$ & $\begin{array}{r}\text { From } 34^{\circ} 53.7^{\prime} \mathrm{N}, \\
\text { to } 34^{\circ} 54.3^{\prime} \mathrm{N},\end{array}$ & $\begin{array}{l}138^{\circ} 38.9^{\prime} \mathrm{E} \\
138^{\circ} 39.1^{\prime} \mathrm{E}\end{array}$ & - & ORI-net \\
\hline 344 & May & 9 & 1969 & $06: 44-07: 51$ & $\begin{array}{r}\text { From } 34^{\circ} 58.7^{\prime} \mathrm{N}, \\
\text { to } 34^{\circ} 57.0^{\prime} \mathrm{N},\end{array}$ & $\begin{array}{l}139^{\circ} 22.5^{\prime} \mathrm{E} \\
139^{\circ} 21.9^{\prime} \mathrm{E}\end{array}$ & $0-1200$ & ORI-net, oblique tow \\
\hline 345 & May & 9 & 1969 & $14: 45-15: 58$ & $\begin{array}{r}\text { From } 34^{\circ} 20.3^{\prime} \mathrm{N}, \\
\text { to } 34^{\circ} 23.3^{\prime} \mathrm{N},\end{array}$ & $\begin{array}{l}138^{\circ} 34.4^{\prime} \mathrm{E} \\
138^{\circ} 35.0^{\prime} \mathrm{E}\end{array}$ & $0-1000$ & ORI-net, oblique tow \\
\hline $363-7$ & May & 10 & 1969 & $15: 02-16: 02$ & $\begin{array}{r}\text { From } 34^{\circ} 52.3^{\prime} \mathrm{N} \\
\text { to } 34^{\circ} 50.4^{\prime} \mathrm{N}\end{array}$ & $\begin{array}{l}138^{\circ} 38.5^{\prime} \mathrm{E} \\
138^{\circ} 38.6^{\prime} \mathrm{E}\end{array}$ & $750-1250$ & ORI-net, horizontal tow \\
\hline 457 & Oct. & 11, & 1970 & $09: 50-11: 05$ & $\begin{array}{r}\text { From } 35^{\circ} 00.5^{\prime} \mathrm{N} \\
\text { to } 34^{\circ} 59.6^{\prime} \mathrm{N}\end{array}$ & $\begin{array}{l}139^{\circ} 21.7^{\prime} \mathrm{E} \\
139^{\circ} 20.6^{\prime} \mathrm{E}\end{array}$ & $0-700$ & ORI-net, oblique tow \\
\hline 526 & Jan. & 24 & 1971 & $05: 22-06: 30$ & $\begin{array}{r}\text { From } 34^{\circ} 54.3^{\prime} \mathrm{N}, \\
\text { to } 34^{\circ} 52.5^{\prime} \mathrm{N},\end{array}$ & $\begin{array}{l}138^{\circ} 38.5^{\prime} \mathrm{E} \\
138^{\circ} 38.4^{\prime} \mathrm{E}\end{array}$ & $0-1200$ & ORI-net, oblique tow \\
\hline 533 & Jan. & 24 & 1971 & $12: 27-12: 50$ & $\begin{array}{r}\text { From } 34^{\circ} 45.3^{\prime} \mathrm{N} \\
\text { to } 34^{\circ} 44.6^{\prime} \mathrm{N},\end{array}$ & $\begin{array}{l}138^{\circ} 22.8^{\prime} \mathrm{E} \\
138^{\circ} 22.7^{\prime} \mathrm{E}\end{array}$ & $570-660$ & Bottom-net \\
\hline
\end{tabular}


Appendix-table 1. (Cont.)

\begin{tabular}{|c|c|c|c|c|c|c|c|}
\hline $\begin{array}{c}\text { Station } \\
\text { no. }\end{array}$ & Date & & Ship time & Positior & & $\begin{array}{l}\text { Sampling } \\
\text { depth (m) }\end{array}$ & Net and remarks \\
\hline 589 & Aug. 17, & 1971 & $12: 27-13: 48$ & $\begin{array}{r}\text { From } 35^{\circ} 03.1^{\prime} \mathrm{N}, \\
\text { to } 35^{\circ} 02.9^{\prime} \mathrm{N},\end{array}$ & $\begin{array}{l}139^{\circ} 18.0^{\prime} \mathrm{E} \\
139^{\circ} 15.7^{\prime} \mathrm{E}\end{array}$ & $0-1350$ & $\begin{array}{l}\text { ORI-net, accidentally touched } \\
\text { the sea-floor in oblique tow }\end{array}$ \\
\hline
\end{tabular}

Appendix-table 2. Hakuho-Maru stations from which the collections reported here were taken.

\begin{tabular}{|c|c|c|c|c|c|c|c|c|c|}
\hline \multirow{2}{*}{$\begin{array}{c}\text { Station } \\
\text { no. }\end{array}$} & \multicolumn{3}{|c|}{ Date } & \multirow{2}{*}{ Ship time } & \multicolumn{3}{|c|}{ Position } & \multirow{2}{*}{$\begin{array}{l}\text { Sampling } \\
\text { depth }(\mathrm{m})\end{array}$} & \multirow{2}{*}{$\frac{\text { Net and remarks }}{\text { ORI-net, horizontal tow }}$} \\
\hline & Dec. & 6 & 1967 & & $\begin{array}{r}\text { From } \\
\text { to }\end{array}$ & $\begin{array}{l}43^{\circ} 56.4^{\prime} \mathrm{N} \\
43^{\circ} 55.9^{\prime} \mathrm{N},\end{array}$ & $\begin{array}{l}149^{\circ} 52.0^{\prime} \mathrm{E} \\
149^{\circ} 53.5^{\prime} \mathrm{E}\end{array}$ & & \\
\hline H9-4 & Dec. & 6 , & 1967 & $12: 54-14: 44$ & $\begin{array}{r}\text { From } \\
\text { to }\end{array}$ & $\begin{array}{l}43^{\circ} 49.8^{\prime} \mathrm{N}, \\
43^{\circ} 49.6^{\prime} \mathrm{N},\end{array}$ & $\begin{array}{l}149^{\circ} 53.1^{\prime} \mathrm{E} \\
149^{\circ} 56.5^{\prime} \mathrm{E}\end{array}$ & $600-750$ & ORI-net, horizontal tow \\
\hline H9-8 & Dec. & $6-7$ & 1967 & $23: 11-02: 14$ & $\begin{array}{r}\text { From } \\
\text { to }\end{array}$ & $\begin{array}{l}43^{\circ} 47.6^{\prime} \mathrm{N}, \\
43^{\circ} 49.3^{\prime} \mathrm{N},\end{array}$ & $\begin{array}{l}149^{\circ} 55.8^{\prime} \mathrm{E} \\
149^{\circ} 57.2^{\prime} \mathrm{E}\end{array}$ & $1300-1700$ & ORI-net, horizontal tow \\
\hline H9-10 & Dec. & 7 & 1967 & $02: 48-04: 05$ & $\begin{array}{r}\text { From } \\
\text { to }\end{array}$ & $\begin{array}{l}43^{\circ} 52.8^{\prime} \mathrm{N}, \\
43^{\circ} 55.8^{\prime} \mathrm{N},\end{array}$ & $\begin{array}{l}149^{\circ} 58.2^{\prime} \mathrm{E} \\
149^{\circ} 59.8^{\prime} \mathrm{E}\end{array}$ & $0-1200$ & ORI-net, oblique tow \\
\hline $\mathrm{H} 10-4$ & Dec. & 9 & 1967 & $06: 53-08: 12$ & $\begin{array}{r}\text { From } \\
\text { to }\end{array}$ & $\begin{array}{l}37^{\circ} 28.2^{\prime} \mathrm{N}, \\
37^{\circ} 26.2^{\prime} \mathrm{N},\end{array}$ & $\begin{array}{l}150^{\circ} 06.1^{\prime} \mathrm{E} \\
150^{\circ} 10.0^{\prime} \mathrm{E}\end{array}$ & $0-1000$ & ORI-net, oblique tow \\
\hline H10-11 & Dec. & 9 & 1967 & $15: 23-17: 35$ & $\begin{array}{r}\text { From } \\
\text { to }\end{array}$ & $\begin{array}{l}37^{\circ} 23.0^{\prime} \mathrm{N}, \\
37^{\circ} 23.5^{\prime} \mathrm{N},\end{array}$ & $\begin{array}{l}150^{\circ} 25.7^{\prime} \mathrm{E} \\
150^{\circ} 25.1^{\prime} \mathrm{F}\end{array}$ & $960-1270$ & ORI-net, horizontal tow \\
\hline $\mathrm{H} 67-1$ & Aug. & 16 & 1969 & $19: 36-20: 45$ & $\begin{array}{r}\text { From } \\
\text { to }\end{array}$ & $\begin{array}{l}40^{\circ} 59.9^{\prime} \mathrm{N}, \\
41^{\circ} 00.3^{\prime} \mathrm{N}\end{array}$ & $\begin{array}{l}165^{\circ} 04.0^{\prime} \mathrm{E} \\
165^{\circ} 07.1^{\prime} \mathrm{E}\end{array}$ & $0-1250$ & ORI-net, oblique tow \\
\hline H84-9 & Aug. & 31 & 1969 & $16: 55-18: 10$ & $\begin{array}{r}\text { From } \\
\text { to }\end{array}$ & $\begin{array}{l}39^{\circ} 47.7^{\prime} \mathrm{N}, \\
39^{\circ} 50.0^{\prime} \mathrm{N},\end{array}$ & $\begin{array}{l}154^{\circ} 36.4^{\prime} \mathrm{W} \\
154^{\circ} 37.1^{\prime} \mathrm{W}\end{array}$ & $0-1150$ & ORI-net, oblique tow \\
\hline H90-6 & Sep. & $2-3$ & 1969 & $23: 36-00: 21$ & $\begin{array}{r}\text { From } \\
\text { to }\end{array}$ & $\begin{array}{l}39^{\circ} 53.4^{\prime} \mathrm{N}, \\
39^{\circ} 54.2^{\prime} \mathrm{N},\end{array}$ & $\begin{array}{l}155^{\circ} 00.6^{\prime} \mathrm{W} \\
155^{\circ} 00.5^{\prime} \mathrm{W}\end{array}$ & $950-1100$ & ORI-net, horizontal tow \\
\hline H91-1 & Sep. & 4 & 1969 & $08: 45-09: 30$ & $\begin{array}{r}\text { From } \\
\text { to }\end{array}$ & $\begin{array}{l}40^{\circ} 05.1^{\prime} \mathrm{N}, \\
40^{\circ} 04.2^{\prime} \mathrm{N},\end{array}$ & $\begin{array}{l}154^{\circ} 51.5^{\prime} \mathrm{W} \\
154^{\circ} 50.0^{\prime} \mathrm{W}\end{array}$ & $950-1100$ & ORI-net, horizontal tow \\
\hline H93-1 & Sep. & 6 , & 1969 & $18: 36-19: 49$ & $\begin{array}{r}\text { From } \\
\text { to }\end{array}$ & $\begin{array}{l}34^{\circ} 58.7^{\prime} \mathrm{N}, \\
34^{\circ} 57.7^{\prime} \mathrm{N},\end{array}$ & $\begin{array}{l}154^{\circ} 53.8^{\prime} \mathrm{W} \\
154^{\circ} 54.8^{\prime} \mathrm{W}\end{array}$ & $0-950$ & ORI-net, oblique tow \\
\hline
\end{tabular}

